This item was submitted to Loughborough's Research Repository by the author.

Items in Figshare are protected by copyright, with all rights reserved, unless otherwise indicated.

\title{
Editor's choice-Biomarkers of acute cardiovascular and pulmonary diseases
}

PLEASE CITE THE PUBLISHED VERSION

https://doi.org/10.1177/2048872616652309

\section{PUBLISHER}

(c) The European Society of Cardiology. Published by Sage

\section{VERSION}

AM (Accepted Manuscript)

\section{PUBLISHER STATEMENT}

This work is made available according to the conditions of the Creative Commons Attribution-NonCommercialNoDerivatives 4.0 International (CC BY-NC-ND 4.0) licence. Full details of this licence are available at: https://creativecommons.org/licenses/by-nc-nd/4.0/

\section{LICENCE}

CC BY-NC-ND 4.0

\section{REPOSITORY RECORD}

Suzuki, Toru, Alexander Lyon, Rajeev Saggar, Liam M. Heaney, Kenichi Aizawa, Antonio Cittadini, Ciro Mauro, et al.. 2019. "Editor's Choice-biomarkers of Acute Cardiovascular and Pulmonary Diseases". figshare. https://hdl.handle.net/2134/33313. 


\title{
BIOMARKERS OF ACUTE CARDIOVASCULAR AND PULMONARY DISEASES
}

\author{
Toru Suzuki, $\mathrm{MD}^{1,2,3}$, Alexander Lyon MD, $\mathrm{PhD}^{4,5}$, Rajeev Saggar, $\mathrm{MD}^{6}$, Liam M. Heaney ${ }^{2,3}$, \\ Kenichi Aizawa, $\mathrm{MD}^{1}$, Antonio Cittadini, $\mathrm{MD}^{7}$, Ciro Mauro, $\mathrm{MD}^{8}$, Rodolfo Citro, $\mathrm{MD}^{9}$, Giuseppe \\ Limongelli, $\mathrm{MD}^{10}$, Francesco Ferrara, MD, $\mathrm{PhD}^{9}$, Olga Vriz, $\mathrm{MD}^{11}$, Andrew Morley-Smith, $\mathrm{MD}^{4,5}$, \\ Paolo Calabrò, $\mathrm{MD}^{10}$ and Eduardo Bossone, $\mathrm{MD}, \mathrm{PhD}^{9}$
}

${ }^{1}$ Department of Cardiovascular Medicine, The University of Tokyo, Tokyo, Japan

${ }^{2}$ Department of Cardiovascular Sciences, University of Leicester, United Kingdom

${ }^{3}$ NIHR Leicester Cardiovascular Biomedical Research Unit, Glenfield Hospital, United Kingdom

${ }^{4}$ National Heart and Lung Institute, Imperial College, London, United Kingdom

${ }^{5}$ NIHR Cardiovascular Biomedical Research Unit, Royal Brompton Hospital, London, United Kingdom

${ }^{6}$ Advanced Lung Disease Institute, Banner Good Samaritan Hospital, Phoenix, Arizona

${ }^{7}$ Department of Medical Translational Sciences, "Federico II" University, Naples, Italy

${ }^{8}$ Division of Cardiology, A.O.R.N. “A. Cardarelli”, Naples, Italy

${ }^{9}$ Heart Department, University Hospital, Salerno, Italy

${ }^{10}$ Division of Cardiology, Monaldi Hospital, Second University of Naples, Naples, Italy

${ }^{11}$ Cardiology and Emergency Department, Sant'Antonio Hospital, San Daniele del Friuli, Udine Italy

The authors report no conflict of interest.

Corresponding author:

Eduardo Bossone, MD, PhD

Cardiology Division, "Cava de' Tirreni and Amalfi Coast” Hospital

Heart Department, University of Salerno - Italy.

Via Principe Amedeo, 36, 83023 Lauro (AV), Italy

Tel/Fax +39 0818240067 - Mobile +39 3285415438 - e-mail: ebossone@hotmail.com

Co-corresponding author:

Toru Suzuki, MD, PhD

Department of Cardiovascular Sciences

University of Leicester

NIHR Leicester Cardiovascular Biomedical Research Unit

Glenfield Hospital

Groby Road, Glenfield, Leicester LE3 9QP, UK

Tel. +4401162874741 - Fax +4401162875792 - e-mail: ts263@le.ac.uk 


\section{ABBREVIATION LIST}

$\mathrm{AAD}=$ acute aortic dissection

ACS $=$ acute coronary syndrome

$\mathrm{AE}=$ acute exacerbation

ARDS = acute respiratory distress syndrome

BNP = B-type natriuretic peptide

CMR = cardiac magnetic resonance

COPD $=$ chronic obstructive pulmonary disease

$\mathrm{C}(\mathrm{P}) \mathrm{K}=$ creatine (phospho-) kinase

$\mathrm{CRP}=\mathrm{C}$-reactive protein

CT = computed tomography

ESC = European Society of Cardiology

$\mathrm{HF}=$ heart failure

GDF-15= growth differentiation factor-15

IL $\quad=$ interleukin

LDL = low-density lipoprotein

$\operatorname{miR}=$ microRNA

$\mathrm{MPO}=$ myeloperoxidase

NLR = negative likelihood ratio

NT-proBNP $=$ N-terminal pro-type B natriuretic peptide

$\mathrm{PE} \quad=$ pulmonary embolism

PLR = positive likelihood ratio

POC = point-of-care

PTX3 = pentraxin 3

sLOX-1 = soluble lectin-like oxidized LDL receptor-1

SP-D = surfactant protein D

STEMI = ST-elevation myocardial infarction

TEFP $=$ troponin-ejection fraction product

TGF $\beta=$ transforming growth factor beta

TTS $=$ Takotsubo syndrome 


\begin{abstract}
Acute cardiothoracic and respiratory diseases frequently remain a challenge to diagnose and differentiate in the emergency setting. The main diseases that manifest with chest pain include ischemic heart disease, myocarditis, acute pericarditis, aortic dissection/rupture and pulmonary embolism (PE). Diseases that primarily present with dyspnea include heart failure (HF), acute respiratory distress syndrome (ARDS), pneumonia, asthma exacerbations and chronic obstructive pulmonary disease. Pre-test probabilities of clinical findings play a vital part in diagnostic decisions, and the use of a Bayesian approach to these greatly improves the ability to stratify patients more accurately. However, blood tests (biomarkers) are increasingly used to assist in rapid decision-making in the emergency setting in combination with imaging methods such as chest radiograph, ultrasound and increasingly computed tomography, as well as physiological tests such as the electrocardiogram in addition to physical examination. Specific tests for ischemic heart disease and myocarditis (cardiac troponins), HF (B-type natriuretic peptide [BNP] and NT-proBNP), aortic dissection (smooth muscle markers) and PE (D-dimer) have been developed. Surfactant protein-D and interleukin- 8 have been developed for ARDS. Additionally, circulating microRNAs have emerged as promising biomarker candidates in cardiovascular disease. With this increasing array of biochemical markers to aid in the diagnosis of chest diseases presenting with chest pain and dyspnea, we herein review the clinical usefulness of these markers, in particular in differentiating cardiac from pulmonary diseases. A symptom-oriented assessment as necessary for use in the critical setting is described in addition to discussion of individual biomarkers.
\end{abstract}

Keywords: biomarkers; chest disease; critical care. 


\section{BIOMARKERS OF ACUTE CARDIOVASCULAR DISEASES}

\section{Acute coronary syndromes}

Acute coronary syndromes (ACS), including acute myocardial infarction and unstable angina, remain the most common pathological entity that has been investigated for biomarker use and development because of their high prevalence worldwide, being the leading cause of mortality in western countries.[1-3]

Most studies in this field have been consistently aimed at early and specific detection of myocardial ischemia/necrosis. While creatine (phospho-)kinase $[\mathrm{C}(\mathrm{P}) \mathrm{K}]$, myoglobin and fatty acid-binding protein have been used historically,[4-6] the emergence of troponin assays has revolutionized our approach to the biochemical diagnosis of acute myocardial ischemia/necrosis. Troponin is an actinbinding protein consisting of $\mathrm{T}$-, I- and $\mathrm{C}$-isoforms with the $\mathrm{T}$ - and I-isoforms being more widely applied to clinical use with the primary reason for differing use lying in proprietary licensing. While earlier troponin assays showed a bi-modal peak,[4] recent development of high-sensitivity troponin assays and their clinical application may provide a new approach to the assessment of myocardial ischemia/necrosis.[5] Assays from multiple vendors are under clinical testing, but generally, they are sensitive enough to measure levels from clinically asymptomatic patients that may have been undetectable previously. Whether elevations in high-sensitivity troponin levels in asymptomatic patients warrant treatment and how to approach such patients are issues yet to be addressed. At present, the European Society of Cardiology (ESC) guidelines suggest that temporal measurements showing increased (i.e., 1.5-fold) or sustained rises (i.e., 1.2-fold) in troponin levels after three hours (as compared to normal upper limit/99 ${ }^{\text {th }}$ percentile) should be considered as diagnostic criteria.[5,6] Measurements at one hour from onset have also been suggested to be sufficient for diagnosis,[7] but in either case, careful interpretation is recommended. It is worth noting that troponin levels can be elevated in the setting of demand ischemia (including effort angina, left ventricular hypertrophy and decompensated heart failure $[\mathrm{HF}]$ ) aside from ACS (Table 1). 
Biomarkers that reflect plaque vulnerability of the coronary arteries to assess early precursory conditions of subsequent plaque rupture/ACS have also been a topic of interest. Markers of plaque formation (e.g., oxidized low-density lipoproteins [LDL]) and inflammation (e.g., interleukin [IL]-6, C-reactive protein [CRP], pentraxin 3 [PTX3]) as well as plaque rupture (e.g., myeloperoxidase [MPO], soluble lectin-like oxidized LDL receptor-1 [sLOX-1]) have been studied. Oxidized LDL cholesterol is a general term used to describe the various oxidized lipid and (phospho-)protein epitopes on the apolipoprotein B molecule. Malondialdehyde modification is thought to be one of the major forms of oxidized LDL. Others that have been pursued include oxidized phosphatidylcholine [8] and sLOX-1, the latter being a $50 \mathrm{kDa}$ membrane protein with an extracellular lectin-like structure that is processed to release a soluble peptide. Studies have shown that oxidized LDL markers are generally formidable markers of ACS with marked elevations in this condition.[9,10] A number of oxidized LDL assays are already commercially available.

Inflammatory markers have been equally pursued. CRP, in particular high-sensitivity assays, and its downstream effector protein, IL-6, have been pursued given that vascular inflammation is an important progressive/acceleratory component of vulnerable plaque instability/rupture aside from its formation as reflected by oxidized LDL. CRP and its 'vascular-selective' component, PTX3, belong to the same PTX domain-containing family of proteins. PTX3 is selective to endothelial cells and macrophages among other vascular cells in contrast to CRP, which is produced predominantly in the liver and is an indicator of the systemic inflammatory response. PTX3 has been shown to be selectively elevated in ACS but not in stable angina.[11]

Another protein of interest is MPO. It is released from blood cells, including granulocytes, in response to external stress and insult, which in turn, cause endothelial dysfunction and foam cell accumulation resulting in progression of plaque instability. Granulocyte infiltration is seen in the plaques of ACS patients,[12] and patients deficient in MPO show delayed progression of heart disease. Importantly, studies have shown that dynamics of MPO activity in the circulation seems to be independent of CRP (inflammation) and thus reflects different components of plaque instability and rupture.[13] As an 
early marker of the vulnerable plaque, likely elevated even in pre-clinical stages, there are expectations that use of MPO will further assist in risk stratification of ACS patients when used in combination with troponin. As these are biomarkers reflective of pathogenic state, serial measurements to assess evolution of the condition rather than use of certain cut-off levels seem most appropriate. Nonetheless, reflecting use of single measurements on admission, sensitivity, specificity, and positive and negative predictive values for MPO $(65.7 \%, 60.7 \%, 53.3 \%$, and $72.2 \%$, respectively) in addition to troponin $\mathrm{T}(58.0 \%, 100.0 \%, 100.0 \%$, and $77.7 \%$, respectively), CK-MB $(42.4 \%, 94.7 \%$, $84.6 \%$, and $70.7 \%$, respectively) and CRP $(31.7 \%, 68.9 \%, 40.6 \%$, and $60.0 \%$, respectively), have been reported as diagnostic performance of cardiac markers in patients with chest pain, whilst acknowledging they may also be elevated in other acute cardiac syndromes, including acute decompensated HF in the absence of chest pain.[13]

In ACS, myocardial injury causes release of microRNAs (miRs) analogous to release of cardiac troponins. miRs are short fragments of non-coding RNA with intricate roles in regulation of gene expression. Alongside their physiological role in individual cell nuclei, they can be isolated from circulating blood or blood components and therein are building momentum as novel biomarkers for a range of clinical scenarios.[14] Several cardiac-specific miRs are released in differing time courses after cell injury, and elegant experiments comparing expression between aortic and coronary sinus venous blood have shown a miR gradient corresponding to release from injured tissue.[15] Amongst others, miR-208, miR-499, miR-1 and miR-133 have been studied as candidates for early diagnosis of ACS, distinguishing patients with myocardial infarction from healthy controls and those with stable coronary artery disease, but existing data fail to provide complete consensus.[16-19] In particular, miR-208 showed promise as an acute diagnostic biomarker with early expression $(<3$ hours) and greater sensitivity than cardiac troponin at early time points, but in other studies miR-208 was not detected or failed to discriminate.[20,21]. Furthermore, MiR biomarkers might also distinguish ACS from other causes of acute chest pain such as Takotsubo syndrome (TTS). Jaguszewski et al. recently 
showed a signature of four miRs that, when assessed together, distinguished STEMI from TTS acutely with good sensitivity and specificity.[22]

\section{Acute 'non-coronary' chest pain syndromes}

\section{Myocarditis}

According to the WHO/ISFC definition, as reported in the recent position statement of the ESC Working Group on Myocardial and Pericardial Diseases, myocarditis is an inflammatory disease of the myocardium diagnosed by established histological, immunological and immunohistochemical criteria, and presenting at all ages with a various array of symptoms.[23] The disease is most frequent in young, previously asymptomatic individuals. Clinical presentation and course are diverse and mainly unpredictable, ranging from mild symptoms of chest pain associated with transient ECG changes to life-threatening new-onset HF, cardiogenic shock and ventricular arrhythmia. The 'ACSlike' presentation is generally characterized by acute chest pain associated with ST-segment elevation or depression and T-wave changes, with or without common risk factors for coronary artery disease; with or without increased troponin T/I (with a time course similar to acute myocardial infarction or a prolonged and sustained release over several weeks or months); with or without normal global or regional left and/or right ventricular dysfunction on echocardiography or cardiac magnetic resonance (CMR); and in the absence of angiographic evidence of coronary artery disease. These episodes are frequently preceded 1-4 weeks by respiratory or gastrointestinal infection.[23] Recently, new diagnostic biomarkers such as brain natriuretic peptides, circulating cytokines, markers related to extracellular matrix degradation, and new biomarkers such as PTX3, galectin-3, and growth differentiation factor-15 (GDF-15) have been proposed to have a potential diagnostic role, but their sensitivity and specificity need further investigation.[24-27] The diagnosis of myocarditis relies, by definition, on cardiac histology and endomyocardial biopsy as the gold standard.[23] However, according to guidelines, endomyocardial biopsy is recommended only in a precise but limited clinical scenario,[28,29] and non-invasive imaging techniques such as T2STIR sequences using CMR 
imaging can be useful in making the diagnosis in 'focal presentation' such as ischemic-like or pseudoinfarction.

\section{Acute pericarditis}

Acute pericarditis is an inflammation of the pericardium with or without pericardial effusion.[30] It has many causes, including idiopathic pericarditis, infections (most cases are presumed to have a viral etiology), renal failure, myocardial infarction (Dressler's syndrome), systemic autoimmune disease, post-cardiac injury syndrome (e.g., postcardiotomy, post-myocardial infarction), malignancy, radiation, and trauma.[30] The most common symptoms include prodromic fever and myalgia, pleuritic chest pain that is relieved by sitting forward and radiates to the trapezius ridge, nonproductive cough, and shortness of breath. The diagnosis of acute pericarditis remains a clinical one based on history, physical examination, ECG (typical anterior and inferior concave ST-segment elevation) and echocardiography (pericardial effusion confirms diagnosis).[31] Appropriate laboratory tests include a complete blood count with differential count, a high-sensitivity CRP test, measurements of troponin I or T and serum creatinine, and liver function tests. High sensitivity CRP is elevated in only around $75 \%$ of cases at clinical presentation, and therefore does not exclude pericarditis, but may show additional benefit when used to monitor therapy. At follow-up, it would be useful to monitor recurrences and to select appropriate therapy duration, preferring non-steroidal anti-inflammatory drug and colchicine.[32] Acute pericarditis may be often accompanied by some degree of myocarditis, which manifests as elevated biomarkers of myocardial injury. In this case, the term "myopericarditis" indicates a primarily pericarditic syndrome with minor myocardial involvement.[30] In this regard, a rise in cardiac troponin $\mathrm{T}$ and $\mathrm{I}$ is a frequent finding, occurring in one third of patients with idiopathic pericarditis and more commonly in younger age.[33,34] Notwithstanding this, the outcome of myopericardial inflammatory syndromes is usually good and troponin elevation is not a negative prognostic marker.[30,33,34] 


\section{Takotsubo syndrome}

TTS is an acute cardiac condition characterized by transient and reversible ventricular dysfunction. The clinical picture of TTS mimics ACS despite the evidence of normal coronary arteries.[35] Although cardiac catheterization is usually required to confirm TTS and to exclude 'culprit' coronary lesions, the profile of cardiac biomarkers can be useful for clinicians in the diagnostic work-up, especially in the early stage.

Compared to acute myocardial infarction where troponin, CK-MB and myoglobin levels are elevated and usually correlated with the extent of myocardial necrosis, TTS is typically associated with mild peak elevations of cardiac enzymes that do not reflect the amount of systolic dysfunction.[35] The striking discrepancy between the degree of myocardial dysfunction on echocardiography or other imaging modalities and the low peak of necrosis enzyme markers is a hallmark of TTS diagnosis.[3537] The reason for this apparent mismatch likely relies on the pathological mechanism of myocardial stunning hypothesized in TTS, related to catecholamine surge secondary to emotional or physical stress.[38]

The clinical course of TTS patients is characterized not only by reduced left ventricular ejection fraction but also by diastolic dysfunction. B-type natriuretic peptide (BNP) levels appear three- to four-fold higher in patients with TTS than with ST-elevation myocardial infarction (STEMI).[39] The increment of BNP in TTS is probably related to increased myocardial wall stress and distention secondary to volume and pressure overload. Madhavan et al. compared biochemical serum indices in TTS versus STEMI patients. They reported an elevated ratio between high BNP and low troponin levels typically associated with TTS.[39] The ratio of BNP to peak troponin T (cut-off $=502$ ) distinguished TTS from STEMI with a sensitivity of $94 \%$ and a specificity of $100 \%$.[39] Similar results were reported by other authors who tested a BNP/CK-MB ratio in a study population including patients with TTS and acute myocardial infarction. In this setting, a cut-off value of $\geq 38$ (obtained from the first simultaneously available serum levels) identified TTS patients with high specificity (99\%) but low sensitivity (46\%).[40] 
Nascimento et al. developed the troponin-ejection fraction product (TEFP) as a new index to differentiate TTS from STEMI.[41] When comparing peak troponin I levels and echocardiographically-derived ejection fraction values in TTS and STEMI patients, they found significantly lower values in the former. Interestingly, TEFP was dramatically lower in TTS (182 \pm 380 vs $4088 \pm 4244, \mathrm{p}<0.001)$. Receiver operating characteristic (ROC) curve analysis showed that TEFP $\geq 250$ had a positive predictive value of $88 \%$ for STEMI and TEFP $<250$ had a negative predictive value of $94 \%$. Therefore, they suggested TEFP as an additional clinical tool to differentiate

\section{TTS from STEMI.[41]}

The study of biomarker kinetics in TTS aims at increasing the ability to diagnose or suspect TTS without using invasive methods. Besides early diagnostic suspicion, biomarkers in TTS are also useful for prognostic purposes. The N-terminal proBNP (NT-proBNP)/troponin T peak level ratio appeared to predict left ventricular function recovery during hospitalization.[42] Conversely, high levels of BNP as well as a high E/e' ratio, an echocardiographic index of diastolic function, were found to correlate with poor prognosis and in-hospital major adverse cardiac events.[43,44] Very

recently, ST2, a receptor of the IL-1 family, has been suggested to improve stratification of in-hospital high-risk patients with TTS.[45] TTS is characterized by a 'unique cardiac biomarker profile' that, when combined with other multimodality imaging parameters, is fundamental for diagnostic orientation and prognostic stratification.

\section{Acute aortic dissection}

Acute aortic dissection (AAD) has a high mortality and morbidity due to potentially fatal complications with a mortality rate of approximately $1 \%$ /hour within the first 24 hours after symptom onset.[46] Even with modern imaging methods, such as computed tomography (CT) and magnetic resonance, or with echocardiography (primarily transesophageal), which can reliably diagnose this condition, $\mathrm{AAD}$ is still often overlooked or misdiagnosed often owing to variability in presentation and lack of suspicion by the attending physician. 


\section{Smooth muscle and vascular markers}

Smooth muscle markers reflect the release of smooth muscle cell proteins following disruption of aortic media layers during dissection. Smooth muscle myosin heavy chain protein was initially pursued, which showed a wide dynamic range (by as much as 20-fold) allowing for accurate diagnosis but was only elevated in the first 3-6 hours after symptom onset. Serial measurements of smooth muscle myosin heavy chain showed sensitivity of $90 \%$, specificity of $97 \%$, positive likelihood ratio (PLR) of 30 and negative likelihood ratio (NLR) of 0.10 at a cut-off value of $2.5 \mathrm{ng} / \mathrm{mL}$ within the first 12 hours.[47-49] A marker with a wider time window was next investigated. The BB-isozyme of $\mathrm{C}(\mathrm{P}) \mathrm{K}$, which is selective for neurological and smooth muscle tissue, was pursued in analogy to the use of the MB-isozyme in myocardial ischemia/necrosis. Results showed peak concentrations were at 6 hours after AAD onset.[50] Further investigation focused on a troponin-like protein of smooth muscle, calponin, in analogy to cardiac troponins in myocardial ischemia/necrosis. Preliminary experience showed selective elevations in type A AAD patients with a moderate diagnostic performance (sensitivity 50\%, specificity 87\%, PLR 3.85 and NLR of 0.57 within 6 hours of symptom onset at a cut-off value of $2.8 \mathrm{ng} / \mathrm{mL}$ ) but with an extended time window of 24 hours.[51] Smooth muscle markers collectively showed promising use in the biochemical diagnosis of AAD and are presently being pursued with hopes of translating to clinical and bedside practice.

Another marker that is elevated in the setting of AAD is elastin, a structural component of the vascular wall.[52] Increasing levels with age and a marginal dynamic range (e.g., 2-fold) with confounding levels have made its clinical use in the present form difficult. However, it is a promising marker that might benefit from improvements. Elastin shows a moderate diagnostic performance with sensitivity of $64.0 \%$, specificity of $94.8 \%$, PLR of 12.3 and NLR of 0.38 at a cut-off point set at the mean +3SD.[52] Matrix metalloproteinase-9, a component of the adventitial remodeling process, has also been shown to be elevated in AAD.[53] Further, CRP as a measure of inflammation was found to be elevated in AAD and to predict outcome.[54-56] 
Transforming growth factor beta (TGF $\beta$ ) is another protein of interest as this factor is the key pathogenic molecule in Marfan syndrome, a genetic disorder affecting fibrillin synthesis in the extracellular matrix of the vascular wall.[57] Studies have identified TGF $\beta$ dysregulation and increased circulating markers of this protein in Marfan patients. Recent evidence has also shown that circulating TGF $\beta$ levels are increased in adult patients with AAD as well, in particular in patients with type A AAD.[58]

\section{Pro-thrombotic markers}

Recent studies have shown that the pro-thrombotic marker D-dimer can be used to both rule in and rule out AAD. The cut-off level generally used to rule out pulmonary embolism (PE) (i.e., $500 \mathrm{ng} / \mathrm{mL}$ ) can reliably be used to rule out AAD as well.[59] A large study examining D-dimer levels in patients with AAD (IRAD-Bio)[60] showed that a normal D-dimer level can reliably rule out AAD in the first 24 hours after onset with a sensitivity of $96.6 \%$ and a NLR of 0.07 , but, more importantly, showed that elevated levels $(>1600 \mathrm{ng} / \mathrm{mL})$ may also rule in AAD if observed within the first 6 hours of symptom. However, this study only included patients with suspected AAD and did not encompass patients with chest pain in general or those with suspected PE. D-dimer is already widely used in the clinic with available point-of-care (POC) devices, and can be used to rule out both AAD as well as PE.[61]

\section{Heart failure}

$\mathrm{HF}$ is the primary cardiac-related disease that requires differentiation from pulmonary disease due to the common presenting symptom of breathlessness. BNP and NT-proBNP are natriuretic peptide biomarkers widely used for the diagnosis of HF. Whereas A-type natriuretic peptide, the prototype of the family, is secreted predominantly from the cardiac atria in response to hemodynamic stress, BNP is released predominantly from the ventricles and thus better reflects HF. With a wide dynamic range, BNP levels are correlated with degree of HF, and show a positive correlation with left ventricular end-diastolic pressure as a hemodynamic measure of HF and with functional impairment as reflected 
by NYHA class.[62-64] Initial studies using BNP in Japan, where this biomarker was developed, used radioimmunoassay methods, but in the United States and elsewhere BNP assays have been introduced in POC forms and, thus, have been widely used in the critical care setting. The Breathing Not Properly study, which examined patients presenting with shortness of breath, showed that BNP measurements could be used to accurately differentiate/triage and risk stratify patients with suspicion of pulmonary or non-cardiac cause of dyspnea.[65] Diagnostic performance at a cut-off value of $100 \mathrm{pg} / \mathrm{mL}$ showed sensitivity of $90 \%$, specificity of $76 \%$, positive predictive value of $79 \%$ and negative predictive value of $89 \%$. BNP is a widely accepted biomarker for HF and is recommended for use in diagnosis of acute HF by major cardiology societies (American College of Cardiology/American Heart Association, ESC, etc.).[66,67] Note that the most recent European guidelines recommend use of BNP to mainly rule out HF.[67]

BNP consists of 32 amino acids and is a bioactive hormone that elicits a natriuretic response in addition to vascular relaxation through actions on its receptors and cyclic guanosine monophosphate second messengers. Likely reflective of necessary metabolic processes, BNP is rapidly degraded in the circulation, showing variable levels according to the clinical condition and timing of measurement. NT-proBNP, which is a relatively stable yet biologically inert processed peptide of the precursor protein of BNP, has also been developed as a biomarker much in analogy to CRP and insulin. NTproBNP generally shows similar diagnostic implications to BNP and has the advantage that it is more stable and therefore can be measured in the community clinics with sample transfer to local hospitals for 'corelab' analysis. However, NT-proBNP is affected more by age and renal function/clearance, making careful assessment necessary to avoid misinterpretation in elderly and renal compromised patients as NT-proBNP tends to be higher in these patients.[68] Patients with decompensated right HF associated with PE will generally present with dyspnea and findings of right ventricular load on echocardiography. BNP (or NT-proBNP) levels are useful because they are elevated in both decompensated right- and left-sided HF. 
A new marker that shows potential promise is soluble ST2 as it appears superior to natriuretic peptides for defining prognosis in HF patients. ST2 is a component of the IL-33 signaling pathway, which is active in HF. Importantly, ST2 signaling is involved in regulating the fibrotic response and, hence, the cardiac remodeling process, which differs from the natriuretic peptide pathway elicited by cardiomyocytes in response to hemodynamic stress. ST2 used in combination with BNP increases diagnostic accuracy and risk stratification of patients with HF in the context of chronic remodeling and prognosis.[69] The main advantage is regarding prognosis and risk stratification, although no study has prospectively shown that ST2 should guide treatment decisions. ST2 has been approved by the DA for clinical use in 2011 and is commercially available.

Galectin-3, a biomarker of fibrosis, has received research interest for its association with heart failure progression. Studies involving both chronic and acute heart failure patients have been able to report additive prognostic value of galectin-3 after admission to hospital with an acute disorder. One experiment reported that elevated levels of galectin-3 were measured in patients who died within 1and 4-years, and that galectin-3 was an independent predictor of 4-year mortality,[70] with another showing that combined use of galectin-3 with NT-proBNP was able to significantly increase prognostic information for short term (60 days) mortality and for a composite of mortality and HF recurrence.[71] However, when galectin-3 was assessed for diagnosis of HF, although median levels were higher in those who were later diagnosed with acute HF, the ROC analysis showed that the diagnostic value of NT-proBNP in these patients was far superior $(\mathrm{AUC}=0.94)$ than galectin-3 (AUC $=0.72$ ). These data suggest that the inclusion of galectin-3 as an emergency department diagnostic test is not likely to provide additive value over the use of NT-proBNP, but its measurement may provide informative data for management of HF progression.

A reasonable emphasis has been placed using miR biomarkers to distinguish HF from respiratory causes. MiR-423-5p has received most attention. It is upregulated in failing human myocardium,[72] and transcoronary gradients suggest that it has a cardiac origin.[73] An initial report showed upregulation in dyspneic patients with HF versus those without HF and healthy controls, with high 
sensitivity and specificity and miR-423-5p levels correlating with NT-proBNP concentrations.[74] These findings were later supported by a larger study that identified a panel of four miRs (including miR-423-5p) distinguishing HF patients from healthy controls more accurately.[75] However, there were mixed signals about relation to disease severity (significant correlation with BNP levels, but no relation with NYHA class or ejection fraction), and in a further study of ischemic HF patients, miR423-5p failed to show an association with markers of HF severity, such as BNP or echocardiographic indices of left ventricular function.[76] miRs show promise as biomarkers in acute cardiac conditions, however larger, correctly powered, prospective clinical studies are required in order to reproduce the findings from the small, largely retrospective experiments. Among other issues is the timescale from sample withdrawal to data output. Technology must be streamlined in order to reduce lengthy processes of RNA isolation and quantification by polymerase chain reaction. Without these improvements to coincide with further research, measurement of miRs cannot become commonplace in the clinical laboratory.

\section{BIOMARKERS OF ACUTE PULMONARY DISEASES}

\section{Pulmonary embolism}

PE along with ACS and AAD represents one of the three major diseases that manifest chest pain as the presenting symptom. As compared to AAD in which patients can pinpoint time of onset by the typical sharp, ripping and moving pain, PE often presents with non-specific symptoms making prompt diagnosis difficult. Plasma D-dimer, a degradation product of cross-linked fibrin, has been extensively studied as a biomarker to rule out this condition and is presently used routinely. A number of D-dimer assays are available. A negative D-dimer result on either quantitative rapid ELISA or second generation latex agglutination tests is diagnostically useful for the exclusion of PE in patients with low to moderate pre-test probability.[77] Plasma D-dimer measurement has limited clinical significance in hospitalized patients or high pre-test probability.[78] The sensitivity, specificity, and NLR of D-dimer testing for deep vein thrombosis in low probability patients have been shown to be 
$88 \%, 72 \%$ and 0.18 , respectively; in moderate probability patients to be $90 \%, 58 \%$ and 0.19 , respectively; and in high probability patients $92 \%, 45 \%$ and 0.16 , respectively.[79] For PE, a sensitivity of $95 \%$ and a NLR of 0.13 have been reported for D-dimer.[59]

It has become increasingly recognized that D-dimer levels increase with age; as such, the clinical utility of using a universal cut-off $(500 \mu \mathrm{g} / \mathrm{L})$ for all age populations is reduced.[80,81] In a recent meta-analysis, a proposed age-adjusted cut-off value (age x $10 \mu \mathrm{g} / \mathrm{L}$ above age 50 years) improved performance characteristics of D-dimer testing, increasing specificity from $34 \%$ to $46 \%$ while maintaining a sensitivity $>97 \%$. $[82,83]$ The recent AJDUST-PE trial studied the diagnostic strategy of using clinical prediction tools to identify patients with non-high pre-test probability for PE and then applied an age-adjusted D-dimer cut-off level. The 3-month failure rate was 1 of 331 patients (0.3\% [0.1\%-1.7\%]).[84] Among patients $>75$ years old, using age-adjusted cut-off rather than traditional $500 \mu \mathrm{g} / \mathrm{L}$ increased proportion of patients in whom PE could be excluded on the basis of D-dimer from $6.4 \%$ to $29.7 \%$, without any additional false-negative findings.[78,84]

Diagnostic strategies in patients suspected of having PE initially focus on identification of patients in whom PE can be ruled out.[77,85] In these strategies, the first step is to assess clinical probability by using either empirical clinical assessment or standardized clinical decision rules (e.g., 2-level Wells, simple-revised Geneva, Pisa, Charlotte, PE rule-out criteria).[86] Multidetector CT angiography +/lower limb compression ultrasonography is recommended for imaging.[61] Outpatients with low clinical probability and a normal chest radiograph, lung scintigraphy (V/Q scan) may be an alternative option, especially in child-bearing women, severe renal failure, and severe contrast-allergic history.[59,78,87,88] As predictive indicators for prognosis of PE, BNP, NT-proBNP, and troponin are useful as they reflect right ventricular overload and subsequent minimal myocardial damage, respectively. While a lower BNP cut-off level of $<50 \mathrm{pg} / \mathrm{mL}$ in patients with PE is associated with a benign clinical course, NT-proBNP concentrations of $600 \mathrm{pg} / \mathrm{mL}$ [81] and elevated troponin I or T levels are associated with risk for short-term death.[89,90] 
Like acute chest pain, several studies have sought miR biomarkers to identify etiology of dyspnea at presentation to the emergency department. In a small study, miR-134 distinguished patients with acute PE from healthy controls and patients with other causes of dyspnea;[91] other groups assessed circulating miRs in chronic obstructive pulmonary disease (COPD) versus asthma.[92] However, there remains very little data on miRs in respiratory disease.

\section{Acute respiratory distress syndrome}

Acute respiratory distress syndrome (ARDS) and acute lung injury are characterized by highpermeability pulmonary edema causing hypoxic respiratory failure with high morbidity and mortality.[93] The encompassing lung injury can either be direct (pulmonary: pneumonia, aspiration) or indirect (extrapulmonary: non-pulmonary sepsis, pancreatitis).[93] Among the several inflammatory biomarkers that have been validated in the diagnosis of ARDS, plasma surfactant protein D (SP-D) and IL-8 can be used in combination with clinical variables for risk prediction.[94] SP-D is a hydrophilic glycoprotein mainly produced by the secretory pathway in type II pneumocytes and can be a specific marker for lung injury.[95] IL-8 is a pro-inflammatory cytokine and is produced by macrophages.[96] IL-8 promotes chemotaxis of neutrophils, causing them to migrate toward the focus of infection, and also enhances neutrophil phagocytosis.[97,98] More recently, angiopoietin-2, a mediator of endothelial injury, was found to be a robust indicator of indirect ARDS, while SP-D was a consistent marker of direct ARDS.[99]. This suggests that direct lung injury is better characterized by severe epithelial lung injury (SP-D, RAGE), and conversely, indirect ARDS is defined by more vascular endothelial inflammation (angiopoietin-2, IL-6, IL-8).[99] BNP at low levels may also help to exclude cardiogenic pulmonary edema.[100] As we gain better understanding of ARDS pathogenesis, biomarkers may help identify patients at highest risk of developing ARDS, assess response to therapy and predict outcome. 


\section{Chronic obstructive pulmonary disease and asthma}

Although COPD and asthma are long-term conditions, both report acute exacerbations (AE) that may lead to presentation to the emergency department. Like other acute cardiovascular events, these can show symptoms of dyspnea, chest discomfort and wheeziness.[101,102] AECOPD have been reported to display elevated levels of GDF-15, CRP and fibrinogen when compared to stable COPD patients, with both acute and stable conditions elevated in comparison to healthy controls.[103] Furthermore, elevated D-dimer levels have been shown to offer both short- and long-term prognostic values post-AECOPD, with those who survived the in-hospital stay reporting 6.5 -fold shorter mean post-admission survival periods.[104] Interestingly, COPD patients with prior myocardial infarction reported greater elevation of troponin $\mathrm{T}$ and CRP than those without following an AECOPD event.[105] In asthma, sufferers of $\mathrm{AE}$ showed higher levels of D-dimer and fibrinogen than individuals with either severe or stable asthma.[106] Increased levels of CRP and procalcitonin have also been used to distinguish between acute asthma and pneumonia presentations and thus aid in the more apt use of antibiotics in these patients.[107] The use of biomarkers such as these can clearly show elevation in both cardiac and pulmonary conditions, and therefore the combined use of biomarkers and clinical investigations is paramount.

The diagnostic and prognostic values of key biomarkers among major cardiovascular diseases are summarized in Tables 2 and 3,[5,6,61,67,78,82,89,108-124] taking into account current guideline recommendations, recent meta-analyses and cohort studies.

\section{SYMPTOM-ORIENTED USE OF BIOMARKERS}

\section{Chest pain}

When examining a patient with chest pain, ACS, AAD and PE are the three potentially life-threatening conditions that should be considered. ACS, including STEMI, can generally be diagnosed by use of troponin measurements, an electrocardiogram and subsequent coronary angiography. Ideally, an 
electrocardiogram should be performed and interpreted as soon as possible at the point of first medical contact. AAD and PE can both be generally targeted by D-dimer testing and further by triple-rule-out CT. Based on these features, when examining a patient with chest pain in the critical setting, in addition to initial interrogation and physical examination, blood tests including troponin and D-dimer along with electrocardiogram and rapid imaging tests such as chest radiograph and, if necessary, echocardiography and/or CT may be warranted. If presenting to a community hospital where resources are limited, biomarkers and imaging will assist in making an early decision whether to transfer to a tertiary center and/or pursue further diagnostic testing (e.g., imaging). The critical role of clinical examination and findings in the interpretation of biomarkers should always be remembered to provide a Bayesian context to the test and results, as the pre-test likelihood of various conditions will be dramatically different based upon clinical data (Figure 1). For example, in the case of a high probability of $\mathrm{PE}$ or $\mathrm{AAD}$, subsequent biomarker tests should be by-passed in favor of sending the patient directly for imaging. Similarly, it is not possible to definitively define HF when NT-proBNP is high (e.g. high risk of PE) and therefore this emphasizes the importance of the pre-test probabilities derived from clinical investigations, using the Bayesian approach, when considering subsequent diagnostic pathways.

\section{Shortness of breath}

Diagnosing whether shortness of breath or dyspnea is of pulmonary or cardiac origin is often difficult because both are frequently present as a complication or sequelae of the other. When examining a patient in the critical setting, in addition to initial interrogation and physical examination, blood tests including BNP along with electrocardiogram and rapid imaging tests such as chest radiograph and, if necessary, echocardiography may be warranted. BNP levels $>400 \mathrm{pg} / \mathrm{mL}$ are strongly suggestive of acute cardiac decompensation, and echocardiography is recommended in patients with suspected HF, including those individuals with serum BNP levels $<100 \mathrm{pg} / \mathrm{mL}$. It should be noted that pulmonary diseases with hemodynamic stress on the right ventricle can raise BNP $>100 \mathrm{pg} / \mathrm{mL}$. 
One condition that should especially be kept in mind when examining patients with suspicion of HF is ARDS. Signs and symptoms of this disease are often similar to lung congestion or abnormal blood gas levels, and may thus mimic HF. However, as rapid deterioration of the condition can occur without appropriate treatment, careful suspicion and observation is warranted. SP-D levels can be helpful, but this is not usually measured routinely in critical care patients with shortness of breath/dyspnea owing to lack of availability of POC tests as compared to cardiac troponins, BNP and D-dimer. At present, given the absence of specific methods to triage patients with ARDS, the suspicion of the attending physician to keep this condition in mind when treating patients with acute shortness of breath, in particular those with no history of heart disease, is of utmost importance. For diagnostic algorithm, see Figure 2.

\section{CONCLUSIONS}

In the present review, we discussed the use of biomarkers in the diagnosis of critical chest diseases. Characteristics and availability of assays are shown in Table 4.[4,5,8-11,47-56,59,60,62-67,69,8790,100,125-129] While much progress has been made in this field, especially for cardiac markers, much more research and development are necessary, in particular for pulmonary diseases. More importantly, as cardiac and pulmonary diseases often acutely affect one another, while the main cause of the condition is diagnosed, there will often be a complex pathophysiology in which both the heart and lungs will be affected. Especially in the critical care setting, deciphering between the two may be challenging and the diagnosis will be made in an evolving and collective manner. Nonetheless, biomarkers, such as cardiac troponins, BNP and D-dimer, have become to play an important role in triaging patients with critical chest diseases. In addition, circulating miRs have emerged as promising novel biomarkers in different disease states, including cardiovascular disease. Further investigations of combined roles with rapid imaging tests and other measures along with their accurate clinical interpretation should prove to be a formidable working diagnostic algorithm as we look to the future. 
Acknowledgment: The authors are grateful to Dr. Luca Carannante, cardiovascular technologist, for technical support. 


\section{REFERENCES}

1. Boden WE, McKay RG. Optimal treatment of acute coronary syndromes--an evolving strategy. N Engl J Med 2001; 344:1939-1342.

2. Yarlagadda RK, Boden WE. Cardioprotective effects of an early invasive strategy for non-STsegment elevation acute coronary syndromes: are we all becoming "interventional" cardiologists? J Am Coll Cardiol 2002;40:1915-1918.

3. Murray CJ, Lopez AD. Alternative projections of mortality and disability by cause 1990-2020: Global Burden of Disease Study. Lancet 1997;349:1498-1504.

4. Katus HA, Remppis A, Looser S, Hallermeier K, Scheffold T, Kubler W. Enzyme linked immuno assay of cardiac troponin $\mathrm{T}$ for the detection of acute myocardial infarction in patients. $\mathrm{J}$ Mol Cell Cardiol 1989; 21:1349-1353.

5. Roffi M, Patrono C, Collet JP, Mueller C, Valgimigli M, Andreotti F, Bax JJ, Borger MA, Brotons C, Chew DP, Gencer B, Hasenfuss G, Kjeldsen K, Lancellotti P, Landmesser U, Mehilli J, Mukherjee D, Storey RF, Windecker S. 2015 ESC Guidelines for the management of acute coronary syndromes in patients presenting without persistent ST-segment elevation: Task Force for the Management of Acute Coronary Syndromes in Patients Presenting without Persistent STSegment Elevation of the European Society of Cardiology (ESC). Eur Heart J 2016;37:267-315.

6. Steg PG, James SK, Atar D, Badano LP, Blömstrom-Lundqvist C, Borger MA, Di Mario C, Dickstein K, Ducrocq G, Fernandez-Aviles F, Gershlick AH, Giannuzzi P, Halvorsen S, Huber K, Juni P, Kastrati A, Knuuti J, Lenzen MJ, Mahaffey KW, Valgimigli M, van 't Hof A, Widimsky P, Zahger D; Task Force on the management of ST-segment elevation acute myocardial infarction of the European Society of Cardiology (ESC). ESC Guidelines for the management of acute myocardial infarction in patients presenting with ST-segment elevation. Eur Heart J 2012;33:2569-2619.

7. Reichlin T, Schindler C, Drexler B, Twerenbold R, Reiter M, Zellweger C, Moehring B, Ziller R, Hoeller R, Rubini Gimenez M, Haaf P, Potocki M, Wildi K, Balmelli C, Freese M, Stelzig C, 
Freidank H, Osswald S, Mueller C. One-hour rule-out and rule-in of acute myocardial infarction using high-sensitivity cardiac troponin T. Arch Intern Med 2012;172:1211-1218.

8. Suzuki T, Kohno H, Hasegawa A, Toshima S, Amaki T, Kurabayashi M, Nagai R, Suzuki T, Amaki T, Nagai R, Hasegawa A, Toshima S, Kurabayashi MH, Shimada K, Nakamura H, Teramoto T, Yamaguchi H, Nishiyama S, Takahashi H, Michishita I, Sugano Z, Konoshi K; Clinical Trial of Oxidized LDL (CTOL) Investigators. Diagnostic implications of circulating oxidized low density lipoprotein levels as a biochemical risk marker of coronary artery disease. Clin Biochem 2002;35:347-353.

9. Amaki T, Suzuki T, Nakamura F, Hayashi D, Imai Y, Morita H, Fukino K, Nojiri T, Kitano S, Hibi N, Yamazaki T, Nagai R. Circulating malondialdehyde modified LDL is a biochemical risk marker for coronary artery disease. Heart 2004;90:1211-1213.

10. Hayashida K, Kume N, Murase T, Minami M, Nakagawa D, Inada T, Tanaka M, Ueda A, Kominami G, Kambara H, Kimura T, Kita T. Serum soluble lectin-like oxidized low-density lipoprotein receptor-1 levels are elevated in acute coronary syndrome: a novel marker for early diagnosis. Circulation 2005;112:812-818.

11. Inoue K, Sugiyama A, Reid PC, Ito Y, Miyauchi K, Mukai S, Sagara M, Miyamoto K, Satoh H, Kohno I, Kurata T, Ota H, Mantovani A, Hamakubo T, Daida H, Kodama T. Establishment of a high sensitivity plasma assay for human pentraxin3 as a marker for unstable angina pectoris. Arterioscler Thromb Vasc Biol 2007; 27:161-167.

12. Naruko T, Ueda M, Haze K, van der Wal AC, van der Loos CM, Itoh A, Komatsu R, Ikura Y, Ogami M, Shimada Y, Ehara S, Yoshiyama M, Takeuchi K, Yoshikawa J, Becker AE. Neutrophil infiltration of culprit lesions in acute coronary syndromes. Circulation 2002;106:2894-2900.

13. Brennan ML, Penn MS, Van Lente F, Nambi V, Shishehbor MH, Aviles RJ, Goormastic M, Pepoy ML, McErlean ES, Topol EJ, Nissen SE, Hazen SL. Prognostic value of myeloperoxidase in patients with chest pain. N Engl J Med 2003;349:1595-1604. 
14. Kumarswamy R, Thum T. Non-coding RNAs in cardiac remodeling and heart failure. Circ Res 2013;113:676-689.

15. De Rosa S, Fichtlscherer S, Lehmann R, Assmus B, Dimmeler S, Zeiher AM. Transcoronary concentration gradients of circulating microRNAs. Circulation 2011;124:1936-1944.

16. Wang GK, Zhu JQ, Zhang JT, Li Q, Li Y, He J, Qin YW, Jing Q. Circulating microRNA: a novel potential biomarker for early diagnosis of acute myocardial infarction in humans. Eur Heart $\mathrm{J}$ 2010;31:659-666.

17. D’Alessandra Y, Devanna P, Limana F, Straino S, Di Carlo A, Brambilla PG, Rubino M, Carena MC, Spazzafumo L, De Simone M, Micheli B, Biglioli P, Achilli F, Martelli F, Maggiolini S, Marenzi G, Pompilio G, Capogrossi MC. Circulating microRNAs are new and sensitive biomarkers of myocardial infarction. Eur Heart J 2010;31:2765-2773.

18. Corsten MF, Dennert R, Jochems S, Kuznetsova T, Devaux Y, Hofstra L, Wagner DR, Staessen JA, Heymans S, Schroen B. Circulating MicroRNA-208b and MicroRNA-499 reflect myocardial damage in cardiovascular disease. Circ Cardiovasc Genet 2010;3:499-506.

19. Widera C, Gupta SK, Lorenzen JM, Bang C, Bauersachs J, Bethmann K, Kempf T, Wollert KC, Thum T. Diagnostic and prognostic impact of six circulating microRNAs in acute coronary syndrome. J Mol Cell Cardiol 2011;51:872-875.

20. Meder B, Keller A, Vogel B, Haas J, Sedaghat-Hamedani F, Kayvanpour E, Just S, Borries A, Rudloff J, Leidinger P, Meese E, Katus HA, Rottbauer W. MicroRNA signatures in total peripheral blood as novel biomarkers for acute myocardial infarction. Basic Res Cardiol 2011;106:13-23.

21. Kuwabara Y, Ono K, Horie T, Nishi H, Nagao K, Kinoshita M, Watanabe S, Baba O, Kojima Y, Shizuta S, Imai M, Tamura T, Kita T, Kimura T. Increased microRNA-1 and microRNA-133a levels in serum of patients with cardiovascular disease indicate myocardial damage. Circ Cardiovasc Genet 2011;4:446-454. 
22. Jaguszewski M, Osipova J, Ghadri JR, Napp LC, Widera C, Franke J, Fijalkowski M, Nowak R, Fijalkowska M, Volkmann I, Katus HA, Wollert KC, Bauersachs J, Erne P, Lüscher TF, Thum T, Templin C. A signature of circulating microRNAs differentiates takotsubo cardiomyopathy from acute myocardial infarction. Eur Heart J 2014;35:999-1006.

23. Caforio A, Pankuweit S, Arbustini E, Basso C, Gimeno-Blanes J, Felix SB, Fu M, Heliö T, Heymans S, Jahns R, Klingel K, Linhart A, Maisch B, McKenna W, Mogensen J, Pinto YM, Ristic A, Schultheiss HP, Seggewiss H, Tavazzi L, Thiene G, Yilmaz A, Charron P, Elliott PM; European Society of Cardiology Working Group on Myocardial and Pericardial Diseases. Current state of knowledge on aetiology, diagnosis, management and therapy of myocarditis: a position statement of the European Society of Cardiology Working Group on Myocardial and Pericardial Diseases. Eur Heart J 2013;34:2636-2648.

24. Jensen J, Ma LP, Fu ML, Svaninger D, Lundberg PA, Hammarsten O. Inflammation increases NT-proBNP and the NT-proBNP/BNP ratio. Clin Res Cardiol 2010;99:445-452.

25. Deswal A, Petersen NJ, FeldmanAM, Young JB, White BG, Mann DL. Cytokines and cytokine receptors in advanced heart failure: an analysis of the cytokine database from the Vesnarinone trial (VEST). Circulation 2001;103:2055-2059.

26. Deardorff R, Spinale FG. Cytokines and matrix metalloproteinases as potential biomarkers in chronic heart failure. Biomark Med 2009;3:513-523.

27. Emdin M, Vittorini S, Passino C, Clerico A. Old and new biomarkers of heart failure. Eur J Heart Fail 2009;11:331-335.

28. Leone O, Veinot JP, Angelini A, Baandrup UT, Basso C, Berry G, Bruneval P, Burke M, Butany J, Calabrese F, d'Amati G, Edwards WD, Fallon JT, Fishbein MC, Gallagher PJ, Halushka MK, McManus B, Pucci A, Rodriguez ER, Saffitz JE, Sheppard MN, Steenbergen C, Stone JR, Tan C, Thiene G, van der Wal AC, Winters GL. 2011 Consensus statement on endomyocardial biopsy from the Association for European Cardiovascular Pathology and the Society for Cardiovascular Pathology. Cardiovasc Pathol 2012;21:245-274. 
29. Cooper LT, Baughman KL, Feldman AM, Frustaci A, Jessup M, Kuhl U, Levine GN, Narula J, Starling RC, Towbin J, Virmani R; American Heart Association; American College of Cardiology; European Society of Cardiology; Heart Failure Society of America; Heart Failure Association of the European Society of Cardiology. The role of endomyocardial biopsy in the management of cardiovascular disease: a scientific statement from the American Heart Association, the American College of Cardiology, and the European Society of Cardiology. Endorsed by the Heart Failure Society of America and the Heart Failure Association of the European Society of Cardiology. J Am Coll Cardiol 2007;50:1914-1931.

30. Adler Y, Charron P, Imazio M, Badano L, Barón-Esquivias G, Bogaert J, Brucato A, Gueret P, Klingel K, Lionis C, Maisch B, Mayosi B, Pavie A, Ristić AD, Sabaté Tenas M, Seferovic P, Swedberg K, Tomkowski W. 2015 ESC Guidelines for the diagnosis and management of pericardial diseases: The Task Force for the Diagnosis and Management of Pericardial Diseases of the European Society of Cardiology (ESC) endorsed by the European Association for CardioThoracic Surgery (EACTS). Eur Heart J 2015;36:2921-2964.

31. LeWinter MM. Clinical practice. Acute pericarditis. N Engl J Med 2014;371:2410-2416.

32. Imazio M, Brucato A, Maestroni S, Cumetti D, Dominelli A, Natale G, Trinchero R. Prevalence of C-reactive protein elevation and time course of normalization in acute pericarditis: implications for the diagnosis, therapy, and prognosis of pericarditis. Circulation 2011;123:10921097.

33. Gamaza-Chulián S, León-Jiménez J, Recuerda-Núñez M, Camacho-Freire S, Gutiérrez-Barrios A, Vargas-Machuca JC. Cardiac troponin-T in acute pericarditis. J Cardiovasc Med 2014;15:6872.

34. Imazio M, Brucato A, Barbieri A, Ferroni F, Maestroni S, Ligabue G, Chinaglia A, Cumetti D, Della Casa G, Bonomi F, Mantovani F, Di Corato P, Lugli R, Faletti R, Leuzzi S, Bonamini R, Modena MG, Belli R. Good prognosis for pericarditis with and without myocardial involvement: results from a multicenter, prospective cohort study. Circulation 2013;128:42-49. 
35. Pilgrim TM, Wyss TR. Takotsubo cardiomyopathy or transient left ventricular apical ballooning syndrome: a systematic review. Int J Cardiol 2008;124:283-292.

36. Citro R, Lyon AR, Meimoun P, Omerovic E, Redfors B, Buck T, Lerakis S, Parodi G, Silverio A, Eitel I, Schneider B, Prasad A, Bossone E. Standard and advanced echocardiography in takotsubo (stress) cardiomyopathy: clinical and prognostic implications. J Am Soc Echocardiogr 2015;28:57-74.

37. Bossone E, Lyon A, Citro R, Athanasiadis A, Meimoun P, Parodi G, Cimarelli S, Omerovic E, Ferrara F, Limongelli G, Cittadini A, Salerno-Uriarte JA, Perrone Filardi P, Schneider B, Sechtem U, Erbel R. Takotsubo cardiomyopathy: an integrated multi-imaging approach. Eur Heart J Cardiovasc Imaging 2014;15:366-377.

38. Wittstein IS, Thiemann DR, Lima JAC, Baughman KL, Schulman SP, Gerstenblith G, Wu KC, Rade JJ, Bivalacqua TJ, Champion HC. Neurohumoral features of myocardial stunning due to sudden emotional stress. N Engl J Med 2005;352:539-548.

39. Madhavan M, Borlaug BA, Lerman A, Rihal CS, Prasad A. Stress hormone and circulating biomarker profile of apical ballooning syndrome (takotsubo cardiomyopathy): insights into the clinical significance of B-type natriuretic peptide and troponin levels. Heart 2009;95:1436-1441.

40. Randhawa MS, Dhillon AS, Taylor HC, Sun Z, Desai MY. Diagnostic utility of cardiac biomarkers in discriminating Takotsubo cardiomyopathy from acute myocardial infarction. $\mathrm{J}$ Card Fail 2014;20:377.e25-31.

41. Nascimento FO, Yang S, Larrauri-Reyes M, Pineda AM, Cornielle V, Santana O, Heimowitz TB, Stone GW, Beohar N. Usefulness of the troponin-ejection fraction product to differentiate stress cardiomyopathy from ST-segment elevation myocardial infarction. Am J Cardiol 2014;113:429433.

42. Fröhlich GM, Schoch B, Schmid F, Keller P, Sudano I, Lüscher TF, Noll G, Ruschitzka F, Enseleit F. Takotsubo cardiomyopathy has a unique cardiac biomarker profile: NT- 
proBNP/myoglobin and NT-proBNP/troponin T ratios for the differential diagnosis of acute coronary syndromes and stress induced cardiomyopathy. Int J Cardiol 2012;154:328-332.

43. Murakami T, Yoshikawa T, Maekawa Y, Ueda T, Isogai T, Konishi Y, Sakata K, Nagao K, Yamamoto T, Takayama M; CCU Network Scientific Committee. Characterization of predictors of in-hospital cardiac complications of takotsubo cardiomyopathy: multi-center registry from Tokyo CCU Network. J Cardiol 2014;63:269-273.

44. Citro R, Rigo F, D’Andrea A, Ciampi Q, Parodi P, Provenza G, Piccolo R, Mirra M, Zito C, Giudice R, Patella MM, Antonini-Canterin F, Bossone E, Piscione F, Salerno-Uriarte J; TakoTsubo Italian Network Investigators. Echocardiographic correlates of acute heart failure, cardiogenic shock, and in-hospital mortality in tako-tsubo cardiomyopathy. JACC Cardiovasc Imaging 2014;7:119-129.

45. Vriz O, Minisini R, Ruscio M, Calabrò P, Bossone E. ST2 marker might help to stratify inhospital high risk patients with Tako-tsubo cardiomyopathy. Eur J Intern Med 2015;26:144-145.

46. Harris KM, Strauss CE, Eagle KA, Hirsch AT, Isselbacher EM, Tsai TT, Shiran H, Fattori R, Evangelista A, Cooper JV, Montgomery DG, Froehlich JB, Nienaber CA; International Registry of Acute Aortic Dissection (IRAD) Investigators. Correlates of delayed recognition and treatment of acute type A aortic dissection: the International Registry of Acute Aortic Dissection (IRAD). Circulation 2011;124:1911-1918.

47. Katoh H, Suzuki T, Hiroi Y, Ohtaki E, Suzuki S, Yazaki Y, Nagai R. Diagnosis of aortic dissection by immunoassay for circulating smooth muscle myosin. Lancet 1995;345:191-192.

48. Suzuki T, Katoh H, Tsuchio Y, Hasegawa A, Kurabayashi M, Ohira A, Hiramori K, Sakomura Y, Kasanuki H, Hori S, Aikawa N, Abe S, Tei C, Nakagawa Y, Nobuyoshi M, Misu K, Sumiyoshi T, Nagai R. Diagnostic implications of elevated levels of smooth-muscle myosin heavy-chain protein in acute aortic dissection. The smooth muscle myosin heavy chain study. Ann Intern Med 2000;133:537-541. 
49. Suzuki T, Katoh H, Watanabe M, Kurabayashi M, Hiramori K, Hori S, Nobuyoshi M, Tanaka H, Kodama K, Sato H, Suzuki S, Tsuchio Y, Yazaki Y, Nagai R. Novel biochemical diagnostic method for aortic dissection. Results of a prospective study using an immunoassay of smooth muscle myosin heavy chain. Circulation 1996; 93:1244-1249.

50. Suzuki T, Katoh H, Kurabayashi M, Yazaki Y, Nagai R. Biochemical diagnosis of aortic dissection by raised concentrations of creatine kinase BB-isozyme. Lancet 1997;350:784-785.

51. Suzuki T, Distante A, Zizza A, Trimarchi S, Villani M, Salerno Uriarte JA, de Luca Tupputi Schinosa L, Renzulli A, Sabino F, Nowak R, Birkhahn R, Hollander JE, Counselman F, Bossone E, Eagle K; International Registry of Acute Aortic Dissection Substudy on Biomarkers (IRADBio) Investigators. Preliminary experience with the smooth muscle troponin-like protein, calponin, as a novel biomarker for diagnosing acute aortic dissection. Eur Heart J 2008;29:14391445.

52. Shinohara T, Suzuki K, Okada M, Shiigai M, Shimizu M, Maehara T, Ohsuzu F. Soluble elastin fragments in serum are elevated in acute aortic dissection. Arterioscler Thromb Vasc Biol 2003;23:1839-1844.

53. Sangiorgi G, Trimarchi S, Mauriello A, Righini P, Bossone E, Suzuki T, Rampoldi V, Eagle KA. Plasma levels of metalloproteinases- 9 and -2 in the acute and subacute phases of type A and type B aortic dissection. J Cardiovasc Med 2006;7:307-315.

54. Kuehl H, Eggebrecht H, Boes T, Antoch G, Rosenbaum S, Ladd S, Bockisch A, Barkhausen J, Erbel R. Detection of inflammation in patients with acute aortic syndrome: comparison of FDGPET/CT imaging and serological markers of inflammation. Heart 2008;94:1472-1477.

55. Makita S, Ohira A, Tachieda R, Itoh S, Moriai Y, Yoshioka K, Niinuma H, Nakamura M, Hiramori K. Behavior of C-reactive protein levels in medically treated aortic dissection and intramural hematoma. Am J Cardiol 2000;86:242-244. 
56. Sakakura K, Kubo N, Ako J, Wada H, Fujiwara N, Funayama H, Ikeda N, Nakamura T, Sugawara Y, Yasu T, Kawakami M, Momomura S. Peak C-reactive protein level predicts long-term outcomes in type B acute aortic dissection. Hypertension 2010;55:422-429.

57. Matt P, Schoenhoff F, Habashi J, Holm T, Van Erp C, Loch D, Carlson OD, Griswold BF, Fu Q, De Backer J, Loeys B, Huso DL, McDonnell NB, Van Eyk JE, Dietz HC; GenTAC Consortium. Circulating transforming growth factor-beta in Marfan syndrome. Circulation 2009;120:526532.

58. Suzuki T, Trimarchi S, Sawaki D, Grassi V, Costa E, Rampoldi V, Nagai R, Eagle K. Circulating transforming growth factor-beta levels in acute aortic dissection. J Am Coll Cardiol 2011;58:775.

59. Stein PD, Hull RD, Patel KC, Olson RE, Ghali WA, Brant R, Biel RK, Bharadia V, Kalra NK. D-dimer for the exclusion of acute venous thrombosis and pulmonary embolism: a systematic review. Ann Intern Med 2004;140:589-602.

60. Suzuki T, Distante A, Zizza A, Trimarchi S, Villani M, Salerno Uriarte JA, De Luca Tupputi Schinosa L, Renzulli A, Sabino F, Nowak R, Birkhahn R, Hollander JE, Counselman F, Vijayendran R, Bossone E, Eagle K; IRAD-Bio Investigators. Diagnosis of acute aortic dissection by D-dimer: the International Registry of Acute Aortic Dissection Substudy on Biomarkers (IRAD-Bio) experience. Circulation 2009;119:2702-2707.

61. Erbel R, Aboyans V, Boileau C, Bossone E, Bartolomeo RD, Eggebrecht H, Evangelista A, Falk V, Frank H, Gaemperli O, Grabenwöger M, Haverich A, Iung B, Manolis AJ, Meijboom F, Nienaber CA, Roffi M, Rousseau H, Sechtem U, Sirnes PA, Allmen RS, Vrints CJ; ESC Committee for Practice Guidelines. 2014 ESC Guidelines on the diagnosis and treatment of aortic diseases: document covering acute and chronic aortic diseases of the thoracic and abdominal aorta of the adult. The Task Force for the Diagnosis and Treatment of Aortic Diseases of the European Society of Cardiology (ESC). Eur Heart J 2014;35:2873-2926.

62. Maisel A. B-type natriuretic peptide levels: a potential novel "white count" for congestive heart failure. J Card Fail 2001;7:183-193. 
63. Troughton RW, Frampton CM, Yandle TG, Espiner EA, Nicholls MG, Richards AM. Treatment of heart failure guided by plasma aminoterminal brain natriuretic peptide (N-BNP) concentrations. Lancet 2000;355:1126-1130.

64. Weinfeld MS, Chertow GM, Stevenson LW. Aggravated renal dysfunction during intensive therapy for advanced chronic heart failure. Am Heart J 1999;138(2 Pt 1):285-290.

65. Maisel AS, Clopton P, Krishnaswamy P, Nowak RM, McCord J, Hollander JE, Duc P, Omland T, Storrow AB, Abraham WT, Wu AH, Steg G, Westheim A, Knudsen CW, Perez A, Kazanegra R, Bhalla V, Herrmann HC, Aumont MC, McCullough PA; BNP Multinational Study Investigators. Impact of age, race, and sex on the ability of B-type natriuretic peptide to aid in the emergency diagnosis of heart failure: results from the Breathing Not Properly (BNP) multinational study. Am Heart J 2004;147:1078-1084.

66. Hunt SA, Abraham WT, Chin MH, Feldman AM, Francis GS, Ganiats TG, Jessup M, Konstam MA, Mancini DM, Michl K, Oates JA, Rahko PS, Silver MA, Stevenson LW, Yancy CW; American College of Cardiology Foundation; American Heart Association. 2009 Focused update incorporated into the ACC/AHA 2005 Guidelines for the diagnosis and management of heart failure in adults: a report of the American College of Cardiology Foundation/American Heart Association Task Force on Practice Guidelines developed in collaboration with the International Society for Heart and Lung Transplantation. J Am Coll Cardiol 2009;53:e1-e90.

67. McMurray JJ, Adamopoulos S, Anker SD, Auricchio A, Böhm M, Dickstein K, Falk V, Filippatos G, Fonseca C, Gomez-Sanchez MA, Jaarsma T, Køber L, Lip GY, Maggioni AP, Parkhomenko A, Pieske BM, Popescu BA, Rønnevik PK, Rutten FH, Schwitter J, Seferovic P, Stepinska J, Trindade PT, Voors AA, Zannad F, Zeiher A; Task Force for the Diagnosis and Treatment of Acute and Chronic Heart Failure 2012 of the European Society of Cardiology, Bax JJ, Baumgartner H, Ceconi C, Dean V, Deaton C, Fagard R, Funck-Brentano C, Hasdai D, Hoes A, Kirchhof P, Knuuti J, Kolh P, McDonagh T, Moulin C, Popescu BA, Reiner Z, Sechtem U, Sirnes PA, Tendera M, Torbicki A, Vahanian A, Windecker S, McDonagh T, Sechtem U, Bonet LA, 
Avraamides P, Ben Lamin HA, Brignole M, Coca A, Cowburn P, Dargie H, Elliott P, Flachskampf FA, Guida GF, Hardman S, Iung B, Merkely B, Mueller C, Nanas JN, Nielsen OW, Orn S, Parissis JT, Ponikowski P; ESC Committee for Practice Guidelines. ESC guidelines for the diagnosis and treatment of acute and chronic heart failure 2012: The Task Force for the Diagnosis and Treatment of Acute and Chronic Heart Failure 2012 of the European Society of Cardiology. Developed in collaboration with the Heart Failure Association (HFA) of the ESC. Eur J Heart Fail 2012;14:803-869.

68. Anwaruddin S, Lloyd-Jones DM, Baggish A, Chen A, Krauser D, Tung R, Chae C, Januzzi JL Jr. Renal function, congestive heart failure, and amino-terminal pro-brain natriuretic peptide measurement: results from the ProBNP Investigation of Dyspnea in the Emergency Department (PRIDE) Study. J Am Coll Cardiol 2006;47: 91-97.

69. Januzzi JL Jr, Peacock WF, Maisel AS, Chae CU, Jesse RL, Baggish AL, O'Donoghue M, Sakhuja R, Chen AA, van Kimmenade RR, Lewandrowski KB, Lloyd-Jones DM, Wu AH. Measurement of the interleukin family member ST2 in patients with acute dyspnea: results from the PRIDE (Pro-Brain Natriuretic Peptide Investigation of Dyspnea in the Emergency Department) study. J Am Coll Cardiol 2007;50:607-613.

70. Shah RV, Chen-Tournoux AA, Picard MH, van Kimmenade RRJ, Januzzi JL. Galectin-3, cardiac structure and function, and long-term mortality in patients with acutely decompensated heart failure. Eur J Heart Fail 2010;12:826-832.

71. van Kimmenade RR, Januzzi JL Jr, Ellinor PT, Sharma UC, Bakker JA, Low AF, Martinez A, Crijns HJ, MacRae CA, Menheere PP, Pinto YM.. Utility of amino-terminal pro-brain natriuretic peptide, galectin-3, and apelin for the evaluation of patients with acute heart failure. J Am Coll Cardiol 2006;48:1217-1224.

72. Thum T, Galuppo P, Wolf C, Fiedler J, Kneitz S, van Laake LW, Doevendans PA, Mummery CL, Borlak J, Haverich A, Gross C, Engelhardt S, Ertl G, Bauersachs J. MicroRNAs in the human heart: a clue to fetal gene reprogramming in heart failure. Circulation 2007;116:258-267. 
73. Goldraich LA, Martinelli NC, Matte U, Cohen C, Andrades M, Pimentel M, Biolo A, Clausell N, Rohde LE. Transcoronary gradient of plasma microRNA 423-5p in heart failure: evidence of altered myocardial expression. Biomarkers 2014;19:135-141.

74. Tijsen AJ, Creemers EE, Moerland PD, de Windt LJ, van der Wal AC, Kok WE, Pinto YM. MiR423-5p as a circulating biomarker for heart failure. Circ Res 2010;106:1035-1039.

75. Goren Y, Kushnir M, Zafrir B, Tabak S, Lewis BS, Amir O. Serum levels of microRNAs in patients with heart failure. Eur J Heart Fail 2012;14:147-154.

76. Bauters C, Kumarswamy R, Holzmann A, Bretthauer J, Anker SD, Pinet F, Thum T. Circulating miR-133a and miR-423-5p fail as biomarkers for left ventricular remodeling after myocardial infarction. Int J Cardiol 2013;168:1837-1840.

77. Bates SM, Jaeschke R, Stevens SM, Goodacre S, Wells PS, Stevenson MD, Kearon C, Schunemann HJ, Crowther M, Pauker SG, Makdissi R, Guyatt GH; American College of Chest Physicians. Diagnosis of DVT: Antithrombotic Therapy and Prevention of Thrombosis, 9th ed: American College of Chest Physicians Evidence-Based Clinical Practice Guidelines. Chest 2012;141(2 Suppl):e351S-418S.

78. Konstantinides SV, Torbicki A, Agnelli G, Danchin N, Fitzmaurice D, Galiè N, Gibbs JS, Huisman MV, Humbert M, Kucher N, Lang I, Lankeit M, Lekakis J, Maack C, Mayer E, Meneveau N, Perrier A, Pruszczyk P, Rasmussen LH, Schindler TH, Svitil P, Vonk Noordegraaf A, Zamorano JL, Zompatori M; Task Force for the Diagnosis and Management of Acute Pulmonary Embolism of the European Society of Cardiology (ESC). 2014 ESC Guidelines on the diagnosis and management of acute pulmonary embolism. Eur Heart J 2014;35:3033-3069.

79. Wells PS, Owen C, Doucette S, Fergusson D, Tran H. Does this patient have deep vein thrombosis? JAMA 2006;295:199-207.

80. Righini M, Goehring C, Bounameaux H, Perrier A. Effects of age on the performance of common diagnostic tests for pulmonary embolism. Am J Med 2000;109:357-361. 
81. Righini M, Nendaz M, Le Gal G, Bounameaux H, Perrier A. Influence of age on the costeffectiveness of diagnostic strategies for suspected pulmonary embolism. J Thromb Haemost 2007;5:1869-1877.

82. Schouten HJ, Geersing GJ, Koek HL, Zuithoff NP, Janssen KJ, Douma RA, van Delden JJ, Moons KG, Reitsma JB. Diagnostic accuracy of conventional or age adjusted D-dimer cut-off values in older patients with suspected venous thromboembolism: systematic review and metaanalysis. BMJ 2013;346: f2492.

83. Douma RA, le Gal G, Söhne M, Righini M, Kamphuisen PW, Perrier A, Kruip MJ, Bounameaux H, Büller HR, Roy PM. Potential of an age adjusted D-dimer cut-off value to improve the exclusion of pulmonary embolism in older patients: a retrospective analysis of three large cohorts. BMJ 2010;340:c1475.

84. Righini M, Van Es J, Den Exter PL, Roy PM, Verschuren F, Ghuysen A, Rutschmann OT, Sanchez O, Jaffrelot M, Trinh-Duc A, Le Gall C, Moustafa F, Principe A, Van Houten AA, Ten Wolde M, Douma RA, Hazelaar G, Erkens PM, Van Kralingen KW, Grootenboers MJ, Durian MF, Cheung YW, Meyer G, Bounameaux H, Huisman MV, Kamphuisen PW, Le Gal G. Ageadjusted D-dimer cutoff levels to rule out pulmonary embolism: the ADJUST-PE study. JAMA $2014 ; 311: 1117-1124$.

85. Kruip MJ, Leclercq MG, van der Heul C, Prins MH, Büller HR. Diagnostic strategies for excluding pulmonary embolism in clinical outcome studies. A systematic review. Ann Intern Med 2003;138:941-951.

86. Kline JA, Courtney DM, Kabrhel C, Moore CL, Smithline HA, Plewa MC, Richman PB, O'Neil BJ, Nordenholz K. Prospective multicenter evaluation of the pulmonary embolism rule-out criteria. J Thromb Haemost 2008;6:772-780.

87. Stein PD, Sostman HD, Bounameaux H, Buller HR, Chenevert TL, Dalen JE, Goodman LR, Gottschalk A, Hull RD, Leeper KV Jr, Pistolesi M, Raskob GE, Wells PS, Woodard PK. Challenges in the diagnosis of acute pulmonary embolism. Am J Med 2008;121:565-571. 
88. Stein PD, Sostman HD, Hull RD, Goodman LR, Leeper KV Jr, Gottschalk A, Tapson VF, Woodard PK. Diagnosis of pulmonary embolism in the coronary care unit. Am J Cardiol 2009;103:881-886.

89. Becattini C, Vedovati MC, Agnelli G. Prognostic value of troponins in acute pulmonary embolism: a meta-analysis. Circulation 2007;116:427-433.

90. Kucher N, Printzen G, Goldhaber SZ. Prognostic role of brain natriuretic peptide in acute pulmonary embolism. Circulation 2003;107:2545-2547.

91. Xiao J, Jing ZC, Ellinor PT, Liang D, Zhang H, Liu Y, Chen X, Pan L, Lyon R, Liu Y, Peng LY, Liang X, Sun Y, Popescu LM, Condorelli G, Chen YH. MicroRNA-134 as a potential plasma biomarker for the diagnosis of acute pulmonary embolism. J Transl Med 2011;9:159.

92. Wang M, Huang Y, Liang Z, Liu D, Lu Y, Dai Y, Feng G, Wang C. Plasma miRNAs might be promising biomarkers of chronic obstructive pulmonary disease. Clin Respir J 2016;10:104-111.

93. Ware LB, Matthay MA. The acute respiratory distress syndrome. N Engl J Med 2000;342:13341349.

94. Ware LB, Koyama T, Billheimer DD, Wu W, Bernard GR, Thompson BT, Brower RG, Standiford TJ, Martin TR, Matthay MA; NHLBI ARDS Clinical Trials Network. Prognostic and pathogenetic value of combining clinical and biochemical indices in patients with acute lung injury. Chest 2010;137:288-296.

95. Pan T, Nielsen LD, Allen MJ, Shannon KM, Shannon JM, Selman M, Mason RJ. Serum SP-D is a marker of lung injury in rats. Am J Physiol Lung Cell Mol Physiol 2002;282:L824-L832.

96. Koch AE, Kunkel SL, Burrows JC, Evanoff HL, Haines GK, Pope RM, Strieter RM. Synovial tissue macrophage as a source of the chemotactic cytokine IL-8. J Immunol 1991;147:21872195.

97. Huber AR, Kunkel SL, Todd RF 3rd, Weiss SJ. Regulation of transendothelial neutrophil migration by endogenous interleukin-8. Science 1991;254:99-102. 
98. Schroder JM, Christophers E. Secretion of novel and homologous neutrophil-activating peptides by LPS-stimulated human endothelial cells. J Immunol 1989;142:244-251.

99. Calfee CS, Janz DR, Bernard GR, May AK, Kangelaris KN, Matthay MA, Ware LB; NIH NHLBI ARDS Network. Distinct molecular phenotypes of direct versus indirect ARDS in single and multi-center studies. Chest 2015;147:1539-1548.

100. Ware LB, Matthay MA. Clinical practice. Acute pulmonary edema. N Engl J Med 2005;353:2788-2796.

101. Vestbo J, Hurd SS, Agustí AG, Jones PW, Vogelmeier C, Anzueto A, Barnes PJ, Fabbri LM, Martinez FJ, Nishimura M, Stockley RA, Sin DD, Rodriguez-Roisin R. Global strategy for the diagnosis, management, and prevention of chronic obstructive pulmonary disease: GOLD executive summary. Am J Respir Crit Care Med 2013;187:347-365.

102. Camargo CA Jr, Rowe BH. Asthma Exacerbations. In: Barnes PJ, Drazen JM, Rennard SI, Thomson NC (eds) Asthma and COPD: basic mechanisms and clinical management. $2^{\text {nd }}$ ed. Waltham, MA: Academic Press, 2008, pp. 775-789.

103. Mutlu LC, Altintas N, Aydin M, Tulubas F, Oran M, Kucukyalin V, Kaplan G, Gurel A. Growth differentiation factor-15 is a novel biomarker predicting acute exacerbation of chronic obstructive pulmonary disease. Inflammation 2015;38:1805-1813.

104. Fruchter O, Yigla M, Kramer MR. D-dimer as a prognostic biomarker for mortality in chronic obstructive pulmonary disease exacerbation. Am J Med Sci 2015;349:29-35.

105. Patel ARC, Kowlessar BS, Donaldson GC, Mackay AJ, Singh R, George SN, Garcha DS, Wedzicha JA, Hurst JR. Cardiovascular risk, myocardial injury, and exacerbations of chronic obstructive pulmonary disease. Am J Respir Crit Care Med 2013;188:1091-1099.

106. Brims FJH, Chauhan AK, Higgins B, Shute JK. Up-regulation of the extrinsic coagulation pathway in acute asthma - a case study. J Asthma 2010;47:695-698.

107. Bafadhel M, Clark TW, Reid C, Medina M-J, Batham S, Barer MR, Nicholson KG, Brightling CE. Procalcitonin and C-reactive protein in hospitalized adult patients with community-acquired 
pneumonia or exacerbation of asthma or COPD. Chest 2011;139:1410-1418.

108. Lipinski MJ, Baker NC, Escárcega RO, Torguson R, Chen F, Aldous SJ, Christ M, Collinson PO, Goodacre SW, Mair J, Inoue K, Lotze U, Sebbane M, Cristol JP, Freund Y, Chenevier-Gobeaux C, Meune C, Eggers KM, Pracoń R, Schreiber DH, Wu AH, Ordoñez-Llanos J, Jaffe AS, Twerenbold R, Mueller C, Waksman R. Comparison of conventional and high-sensitivity troponin in patients with chest pain: a collaborative meta-analysis. Am Heart J 2015;169:6-16.

109. Zhelev Z, Hyde C, Youngman E, Rogers M, Fleming S, Slade T, Coelho H, Jones-Hughes T, Nikolaou V. Diagnostic accuracy of single baseline measurement of Elecsys Troponin T highsensitive assay for diagnosis of acute myocardial infarction in emergency department: systematic review and meta-analysis. BMJ 2015;350:h15.

110. Raskovalova T, Twerenbold R, Collinson PO, Keller T, Bouvaist H, Folli C, Giavarina D, Lotze U, Eggers KM, Dupuy AM, Chenevier-Gobeaux C, Meune C, Maisel A, Mueller C, Labarère J. Diagnostic accuracy of combined cardiac troponin and copeptin assessment for early rule-out of myocardial infarction: a systematic review and meta-analysis. Eur Heart J Acute Cardiovasc Care 2014;3:18-27.

111. Ricci F, Di Scala R, Massacesi C, Di Nicola M, Cremonese G, De Pace D, Rossi S, Griffo I, Cataldo I, Martinotti S, Rotondo D, Jaffe AS, Zimarino M, De Caterina R. Ultra-sensitive copeptin and cardiac troponin in diagnosing non-ST-elevation acute coronary syndromes - the COPACS Study. Am J Med 2016;129:105-114.

112. Roberts E, Ludman AJ, Dworzynski K, Al-Mohammad A, Cowie MR, McMurray JJ, Mant J; NICE Guideline Development Group for Acute Heart Failure. The diagnostic accuracy of the natriuretic peptides in heart failure: systematic review and diagnostic meta-analysis in the acute care setting. BMJ 2015;350:h910.

113. Asha SE, Miers JW. A systematic review and meta-analysis of D-dimer as a rule-out test for suspected acute aortic dissection. Ann Emerg Med 2015;66:368-378.

114. Gorla R, Erbel R, Kahlert P, Tsagakis K, Jakob H, Mahabadi AA, Schlosser T, Eggebrecht H, 
Bossone E, Jánosi RA. Accuracy of a diagnostic strategy combining aortic dissection detection risk score and D-dimer levels in patients with suspected acute aortic syndrome. Eur Heart J Acute Cardiovasc Care 2015 Jul 16 [Epub ahead of print].

115. Heidenreich PA, Alloggiamento T, Melsop K, McDonald KM, Go AS, Hlatky MA. The prognostic value of troponin in patients with non-ST elevation acute coronary syndromes: a meta-analysis. J Am Coll Cardiol 2001;38:478-485.

116. Troughton RW, Frampton CM, Brunner-La Rocca HP, Pfisterer M, Eurlings LW, Erntell H, Persson H, O'Connor CM, Moertl D, Karlström P, Dahlström U, Gaggin HK, Januzzi JL, Berger R, Richards AM, Pinto YM, Nicholls MG. Effect of B-type natriuretic peptide-guided treatment of chronic heart failure on total mortality and hospitalization: an individual patient meta-analysis. Eur Heart J 2014;35:1559-1567.

117. Braga JR, Tu JV, Austin PC, Chong A, You JJ, Farkouh ME, Ross HJ, Lee DS. Outcomes and care of patients with acute heart failure syndromes and cardiac troponin elevation. Circ Heart Fail 2013;6:193-202.

118. Parissis JT, Papadakis J, Kadoglou NP, Varounis C, Psarogiannakopoulos P, Rafouli-Stergiou P, Ikonomidis I, Paraskevaidis I, Dimopoulou I, Zerva A, Dima K, Anastasiou-Nana M, Filippatos G. Prognostic value of high sensitivity troponin $\mathrm{T}$ in patients with acutely decompensated heart failure and non-detectable conventional troponin T levels. Int J Cardiol 2013;168:3609-3612.

119. Huang B, Yang Y, Lu H, Zhao Z, Zhang S, Hui R, Fan X. Impact of d-Dimer levels on admission on inhospital and long-term outcome in patients with type A acute aortic dissection. Am J Cardiol $2015 ; 115: 1595-1600$.

120. Wen D, Du X, Dong JZ, Zhou XL, Ma CS. Value of D-dimer and C reactive protein in predicting inhospital death in acute aortic dissection. Heart 2013;99:1192-1197.

121. Klok FA, Mos IC, Huisman MV. Brain-type natriuretic peptide levels in the prediction of adverse outcome in patients with pulmonary embolism: a systematic review and meta-analysis. Am J Respir Crit Care Med 2008;178:425-430. 
122. Lankeit M, Jiménez D, Kostrubiec M, Dellas C, Kuhnert K, Hasenfuss G, Pruszczyk P, Konstantinides S. Validation of N-terminal pro-brain natriuretic peptide cut-off values for risk stratification of pulmonary embolism. Eur Respir J 2014;43:1669-1677.

123. Lankeit M, Jiménez D, Kostrubiec M, Dellas C, Hasenfuss G, Pruszczyk P, Konstantinides S. Predictive value of the high-sensitivity troponin T assay and the simplified pulmonary embolism severity index in hemodynamically stable patients with acute pulmonary embolism: a prospective validation study. Circulation 2011;124:2716-2724.

124. Dellas C, Puls M, Lankeit M, Schafer K, Cuny M, Berner M, Hasenfuss G, Konstantinides S. Elevated heart-type fatty acid-binding protein levels on admission predict an adverse outcome in normotensive patients with acute pulmonary embolism. J Am Coll Cardiol 2010;55:21502157.

125. Inoue K, Suwa S, Ohta H, Itoh S, Maruyama S, Masuda N, Sugita M, Daida H. Heart fatty acidbinding protein offers similar diagnostic performance to high-sensitivity troponin $\mathrm{T}$ in emergency room patients presenting with chest pain. Circ J 2011;75:2813-2820.

126. Moe GW, Ezekowitz JA, O'Meara E, Lepage S, Howlett JG, Fremes S, Al-Hesayen A, Heckman GA, Abrams H, Ducharme A, Estrella-Holder E, Grzeslo A, Harkness K, Koshman SL, McDonald M, McKelvie R, Rajda M, Rao V, Swiggum E, Virani S, Zieroth S, Arnold JM, Ashton T, D'Astous M, Chan M, De S, Dorian P, Giannetti N, Haddad H, Isaac DL, Kouz S, Leblanc MH, Liu P, Ross HJ, Sussex B, White M; Canadian Cardiovascular Society. The 2014 Canadian Cardiovascular Society Heart Failure Management Guidelines Focus Update: anemia, biomarkers, and recent therapeutic trial implications. Can J Cardiol 2015;31:3-16.

127. Kohno N, Kyoizumi S, Awaya Y, Fukuhara H, Yamakido M, Akiyama M. New serum indicator of interstitial pneumonitis activity. Sialylated carbohydrate antigen KL-6. Chest 1989;96:68-73.

128. Yokoyama A, Kondo K, Nakajima M, Matsushima T, Takahashi T, Nishimura M, Bando M, Sugiyama Y, Totani Y, Ishizaki T, Ichiyasu H, Suga M, Hamada H, Kohno N. Prognostic value of circulating KL-6 in idiopathic pulmonary fibrosis. Respirology 2006;11:164-168. 
129. Stahel RA, Gilks WR, Lehmann HP, Schenker T. Third International Workshop on Lung Tumor and Differentiation Antigens: overview of the results of the central data analysis. Int J Cancer Suppl 1994;8:6-26. 


\section{FIGURE LEGENDS}

Figure 1. Diagnostic algorithm for patients presenting to the emergency room with chest pain using high-sensitivity troponin and D-dimer as well as electrocardiogram and rapid imaging. ACS, acute coronary syndrome; AD, aortic dissection; EMB, endomyocardial biopsy; CT, computed tomography; ECG, electrocardiogram; MRI, magnetic resonance imaging; PCI, percutaneous coronary intervention; PE, pulmonary embolism; STEMI, ST-elevation myocardial infarction.

Figure 2. Diagnostic algorithm for patients presenting to the emergency room with shortness of breath using BNP and D-dimer as well as electrocardiogram and rapid imaging.

$\mathrm{AD}$, aortic dissection; ARDS, acute respiratory distress syndrome; BNP, B-type natriuretic peptide; CT, computed tomography; ECG, electrocardiogram; HF, heart failure; NT-proBNP, N-terminal proBNP; PE, pulmonary embolism. 
Table 1. Possible causes of troponin elevation.

\begin{tabular}{|c|c|}
\hline Troponin elevation & Possible causes \\
\hline High & $\begin{array}{l}\text { Large myocardial infarction } \\
\text { Severe myocarditis }\end{array}$ \\
\hline Medium & $\begin{array}{l}\text { Medium size myocardial infarction } \\
\text { Hypotension/shock } \\
\text { Perimyocarditis } \\
\text { Sepsis } \\
\text { Pulmonary embolism } \\
\text { Acute heart failure } \\
\text { Renal dysfunction } \\
\text { Tako-tsubo syndrome } \\
\text { Radiofrequency catheter ablation } \\
\text { Cardiac contusion } \\
\text { Acute aortic dissection } \\
\text { Acute respiratory distress syndrome }\end{array}$ \\
\hline Low & $\begin{array}{l}\text { Chronic heart failure } \\
\text { Left ventricular hypertrophy } \\
\text { Stable angina } \\
\text { Subclinical heart disease } \\
\text { Strenuous exercise } \\
\text { Tachyarrhythmias } \\
\text { Stroke } \\
\text { Endocarditis } \\
\text { Chemotherapy } \\
\text { Sympathomimetic drugs }\end{array}$ \\
\hline
\end{tabular}


Table 2. Diagnostic value of key biomarkers in major acute cardiovascular diseases.[5,6,61,67,78]

\begin{tabular}{|c|c|c|c|c|c|c|c|c|}
\hline Disease & Biomarker & $\begin{array}{c}\text { Population } \\
\text { Study design }\end{array}$ & Cut-off value & $\begin{array}{c}\text { Sensitivity, \% } \\
\text { (95\% CI) }\end{array}$ & $\begin{array}{l}\text { Specificity, \% } \\
\text { (95\% CI) }\end{array}$ & $\begin{array}{c}\text { NPV, \% } \\
(95 \% \text { CI) }\end{array}$ & $\begin{array}{c}\text { PPV, \% } \\
(95 \% \text { CI) }\end{array}$ & Remarks \\
\hline \multirow[t]{4}{*}{$\begin{array}{l}\text { Acute } \\
\text { myocardial } \\
\text { infarction }\end{array}$} & cTn (baseline) & \multirow{2}{*}{$\begin{array}{c}8644 \\
\text { Meta-analysis }^{108}\end{array}$} & \multirow{2}{*}{$\begin{array}{l}\text { Different } \\
\text { assays and } \\
\text { cut-off }\end{array}$} & 74.9 & 93.8 & 93.5 & 75.9 & $\begin{array}{l}\text { The second cTn assay had } \\
\text { significantly greater specificity } \\
(\mathrm{p}<0.001), \text { PPV }(\mathrm{p}<0.001) \text {, and LR }+ \\
(\mathrm{p}<0.01) \text { than the second hs-cTn } \\
\text { assay. }\end{array}$ \\
\hline & hs-cTn (baseline) & & & 88.4 & 81.6 & 96.4 & 55.8 & $\begin{array}{l}\text { Sensitivity remained significantly } \\
\text { greater for the second hs-cTn assay } \\
\text { compared with the second } \\
\text { cTn assay }(\mathrm{p}<0.05) \text {. }\end{array}$ \\
\hline & \multirow[t]{2}{*}{$\begin{array}{l}\text { hs-cTn T } \\
\text { (Elecsys) }\end{array}$} & \multirow{2}{*}{$\begin{array}{c}- \\
\text { Meta-analysis }^{109}\end{array}$} & $14 \mathrm{ng} / \mathrm{L}$ & $\begin{array}{c}89.5 \\
86.3-92.1\end{array}$ & $\begin{array}{c}77.1 \\
68.7-83.7\end{array}$ & $\begin{array}{c}\text { LR- }=0.14 \\
0.10-0.18\end{array}$ & $\begin{array}{c}\mathrm{LR}+=3.9 \\
2.8-5.4\end{array}$ & \multirow{2}{*}{$\begin{array}{l}\text { Single baseline measurement may } \\
\text { not be appropriate for patients who } \\
\text { present less than } 3 \text { hours after } \\
\text { symptom onset. }\end{array}$} \\
\hline & & & $3-5 \mathrm{ng} / \mathrm{L}$ & $\begin{array}{c}97.4 \\
94.9-98.7\end{array}$ & $\begin{array}{c}42.4 \\
31.2-54.5\end{array}$ & $\begin{array}{c}\text { LR- }=0.06 \\
0.04-0.10\end{array}$ & $\begin{array}{c}\mathrm{LR}+=1.69 \\
1.40-2.05\end{array}$ & \\
\hline & $\begin{array}{l}\text { Combined } \\
\text { copeptin and } \\
\text { cTn }(\mathrm{I} \text { and } \mathrm{T})\end{array}$ & $\begin{array}{c}6988 \\
\text { Meta-analysis }^{110}\end{array}$ & $\begin{array}{r}\text { Copeptin } \\
14 \mathrm{pmol} / \mathrm{L}\end{array}$ & $\begin{array}{c}95 \\
89-98\end{array}$ & $\begin{array}{c}57 \\
49-65\end{array}$ & $\begin{array}{c}\text { LR- }=0.07 \\
0.02-0.11\end{array}$ & $\begin{array}{c}\mathrm{LR}+=2.19 \\
1.89-2.4\end{array}$ & $\begin{array}{l}\text { Further studies are needed to } \\
\text { establish the utility of combination } \\
\text { of copeptin with hs-cTn without } \\
\text { serial testing. }\end{array}$ \\
\hline NSTEMI & $\begin{array}{l}\text { Combined } \\
\text { ms-cTn I and } \\
\text { us-Cop }\end{array}$ & $\begin{array}{c}196 \\
\text { Prospective }^{111}\end{array}$ & $\begin{array}{c}\text { Us-Cop } \\
10 \mathrm{pmol} / \mathrm{L} \\
\mathrm{ms}-\mathrm{cTn} \mathrm{I} \\
0.045 \mu \mathrm{g} / \mathrm{L}\end{array}$ & $\begin{array}{c}100 \\
-\end{array}$ & $\begin{array}{c}74.2 \\
-\end{array}$ & $\begin{array}{c}100 \\
-\end{array}$ & $\begin{array}{c}40.3 \\
-\end{array}$ & $\begin{array}{l}\text { Diagnostic performance of } \\
\text { combined us-Cop/ms-cTnI single- } \\
\text { sampling strategy was non-inferior } \\
\text { to the serial assessment of ms-cTn I } \\
\text { within } 3 \text { h. Sensitivity }(100 \% \text { vs } \\
89.7 \% \text {; }=\text { NS) was also not } \\
\text { significantly different. }\end{array}$ \\
\hline \multirow[t]{2}{*}{$\begin{array}{l}\text { Acute heart } \\
\text { failure }\end{array}$} & $\mathrm{BNP}$ & \multirow{2}{*}{$\begin{array}{c}15263 \\
\text { Meta-analysis }^{112}\end{array}$} & $\leq 100 \mathrm{ng} / \mathrm{L}$ & $\begin{array}{c}95 \\
0.93-0.96\end{array}$ & $\begin{array}{c}63 \\
0.52-0.73\end{array}$ & $\begin{array}{c}94 \\
0.90-0.96\end{array}$ & $\begin{array}{c}67 \\
0.63-0.75\end{array}$ & \multirow{2}{*}{$\begin{array}{l}\text { No statistical difference in } \\
\text { diagnostic accuracy between BNP } \\
\text { and NT-proBNP. }\end{array}$} \\
\hline & NT-proBNP & & $\leq 300 \mathrm{ng} / \mathrm{L}$ & $\begin{array}{c}99 \\
0.97-1.00\end{array}$ & $\begin{array}{c}43 \\
0.26-0.62\end{array}$ & $\begin{array}{c}98 \\
0.89-1.0\end{array}$ & $\begin{array}{c}0.64 \\
0.57-0.73\end{array}$ & \\
\hline \multirow[t]{2}{*}{$\begin{array}{l}\text { Acute aortic } \\
\text { syndrome }\end{array}$} & D-dimer & $\begin{array}{c}1557 \\
\text { Meta-analysis }^{113}\end{array}$ & $0.50 \mathrm{mg} / \mathrm{L}$ & $\begin{array}{c}98 \\
96.3-99.1\end{array}$ & $\begin{array}{c}41.9 \\
39.0-44.9\end{array}$ & $\begin{array}{c}\text { LR- }=0.05 \\
0.03-0.09\end{array}$ & $\begin{array}{c}\mathrm{LR}+=2.11 \\
1.46-3.05\end{array}$ & $\begin{array}{l}\text { When applied to a low risk } \\
\text { population as defined by the } \\
\text { American Heart Association, the } \\
\text { post-test probability AAD was } \\
0.3 \% \text {. }\end{array}$ \\
\hline & $\begin{array}{l}\text { ADD risk score } \\
\text { with D-dimer }\end{array}$ & $\begin{array}{c}376 \\
\text { Retrospective }^{114}\end{array}$ & $\geq 1$ & 98.8 & 64.6 & 99.5 & 44.9 & $\begin{array}{l}\text { A 'low probability' score combined } \\
\text { with negative D-dimer safely and } \\
\text { efficiently ruled out AAS with a low } \\
\text { failure rate of } 1.1 \% \text {. }\end{array}$ \\
\hline $\begin{array}{l}\text { Pulmonary } \\
\text { embolism }\end{array}$ & D-dimer & $\begin{array}{c}12497 \\
\text { Meta-analysis }^{82}\end{array}$ & Age-adjusted $\dagger$ & $\begin{array}{c}97.8 \\
95.9-98.9\end{array}$ & $\begin{array}{c}48.8 \\
42.9-54.7\end{array}$ & - & - & $\begin{array}{l}\text { Sensitivities of the age-adjusted cut- } \\
\text { off remained above } 97 \% \text { in all age } \\
\text { categories. }\end{array}$ \\
\hline
\end{tabular}


AAS, acute aortic syndrome; ADD, aortic dissection detection; BNP, B-type natriuretic peptide; cTn, cardiac troponin; hs, high sensitivity; IMH, intramural hematoma; LR-, negative likelihood ratio; LR+, positive likelihood ratio; ms, medium sensitivity; NPV, negative predictive value; NSTEMI, non-ST-elevation myocardial infarction; NT-proBNP, N-terminal pro-type B natriuretic peptide; PPV, positive predictive value; us-Cop, ultrasensitive copeptin; -, not reported.

$\dagger$ The age-adjusted cut-off value was defined as age (years) $\times 10 \mu \mathrm{g} / \mathrm{L}$ for patients aged over 50 years (for example, for a patient aged 78 years, the D-dimer concentration would be considered normal below $780 \mu \mathrm{g} / \mathrm{L})$. 
Table 3. Key biomarkers for in-hospital mortality prediction of major acute cardiovascular diseases. $[5,6,61,67,78]$

\begin{tabular}{|c|c|c|c|c|c|c|c|c|c|}
\hline Disease & Biomarker & $\begin{array}{l}\text { Population } \\
\text { Study design }\end{array}$ & $\begin{array}{l}\text { Cut-off } \\
\text { value }\end{array}$ & $\begin{array}{c}\text { Sensitivity, \% } \\
\text { (95\% CI) }\end{array}$ & $\begin{array}{l}\text { Specificity, \% } \\
(95 \% \mathrm{CI})\end{array}$ & $\begin{array}{l}\text { NPV, \% } \\
(95 \% \text { CI) }\end{array}$ & $\begin{array}{c}\text { PPV, \% } \\
(95 \% \text { CI) }\end{array}$ & $\begin{array}{c}\text { OR or HR } \\
(95 \% \mathrm{CI}) \\
\text { p value }\end{array}$ & Remarks \\
\hline $\begin{array}{l}\text { Non-ST- } \\
\text { elevation acute } \\
\text { coronary } \\
\text { syndrome }\end{array}$ & cTn T and I & $\begin{array}{c}5360 \\
\text { Meta-analysis }^{115}\end{array}$ & $\begin{array}{l}\text { Positive } \\
\text { troponin }\end{array}$ & - & - & - & - & $\begin{array}{c}3.1 \\
(2.3-4.1)\end{array}$ & $\begin{array}{l}\text { The prognostic value of troponin } \\
\text { was lower in clinical trials than in } \\
\text { cohort studies. }\end{array}$ \\
\hline $\begin{array}{l}\text { Acute } \\
\text { myocardial } \\
\text { infarction }\end{array}$ & hs-cTn & $\begin{array}{c}8644 \\
\text { Meta-analysis }^{108}\end{array}$ & $\begin{array}{l}\text { Different } \\
\text { assays and } \\
\text { cut-off }\end{array}$ & - & - & - & - & $\begin{array}{c}5.77 \\
3.91-8.51\end{array}$ & $\begin{array}{l}\text { Elevation of baseline hs-cTn, but } \\
\text { negative baseline cTn, was } \\
\text { associated with increased risk of } \\
\text { death or nonfatal MI during follow- } \\
\text { up }(p<0.001) \text { compared with both } \\
\text { negative. }\end{array}$ \\
\hline \multirow[t]{3}{*}{ Heart failure } & $\begin{array}{l}\text { BNP and } \\
\text { NT-proBNP }\end{array}$ & $\begin{array}{c}2000 \\
\text { Meta-analysis }^{116}\end{array}$ & $\begin{array}{l}\text { Natriuretic } \\
\text { peptide- } \\
\text { guided } \\
\text { treatment }\end{array}$ & - & - & - & - & $\begin{array}{c}0.62 \\
(0.45-0.86) \\
\mathrm{p}=0.004\end{array}$ & $\begin{array}{l}\text { Reduces all-cause mortality in } \\
\text { patients aged }<75 \text { years and overall } \\
\text { reduces during follow-up acute } \\
\text { heart failure events and } \\
\text { cardiovascular hospitalization. }\end{array}$ \\
\hline & $\mathrm{cTn}$ & $\begin{array}{c}13656 \\
\text { Cohort study }\end{array}$ & $\begin{array}{l}\text { Different } \\
\text { assays and } \\
\text { cut-off }\end{array}$ & - & - & - & - & $\begin{array}{c}9.17 \\
(8.31-10.12) \\
\mathrm{p}<0.001\end{array}$ & $\begin{array}{l}\mathrm{HR}=5.14(\mathrm{p}<0.001) \text { for } \\
\text { cardiovascular readmission, and } \\
13.08(\mathrm{p}<0.001) \text { for ischemic heart } \\
\text { disease hospitalization }\end{array}$ \\
\hline & hs-cTn & $\begin{array}{c}113 \\
\text { Prospective } 118\end{array}$ & $>77 \mathrm{pg} / \mathrm{mL}$ & $\begin{array}{c}61.5 \\
(51.6-84.5)\end{array}$ & 72.2 & - & - & $\begin{array}{c}1.003 \\
1.001-1.005 \\
\mathrm{P}=0.008\end{array}$ & $\begin{array}{l}\text { On admission, patients presented } \\
\text { with normal conventional (4th } \\
\text { generation) TnT levels }(<0.03 \\
\mathrm{ng} / \mathrm{mL}) \text {. }\end{array}$ \\
\hline \multirow[t]{4}{*}{ Aortic dissection } & D-dimer & $\begin{array}{c}231 \\
\text { Prospective }{ }^{114}\end{array}$ & $\begin{array}{c}\text { Mean } \\
\text { D-dimer } \\
\sim 9 \mathrm{mg} / \mathrm{L}\end{array}$ & $\begin{array}{c}99 \dagger \\
(94-98)\end{array}$ & 67 & LR- $=0.01$ & $\mathrm{LR}+=3.0$ & $\begin{array}{c}5.60 \\
(1.29-24.29) \\
\mathrm{p}=0.022\end{array}$ & $\begin{array}{l}\text { The prognostic role of D-dimer was } \\
\text { not confirmed at 3-year follow-up. }\end{array}$ \\
\hline & D-dimer & $\begin{array}{c}212 \\
\text { Prospective }^{119}\end{array}$ & $>6.10 \mu \mathrm{g} / \mathrm{mL}$ & NR & - & - & - & $\begin{array}{c}6.12 \\
(1.35-27.89) \\
p=0.019\end{array}$ & $\begin{array}{l}\text { D-dimer levels on admission failed } \\
\text { to predict long-term mortality. }\end{array}$ \\
\hline & D-dimer & $\begin{array}{c}114 \\
\text { Prospective }\end{array}$ & $\geq 5.67 \mu \mathrm{g} / \mathrm{mL}$ & $\begin{array}{c}90.3 \\
(85-96)\end{array}$ & 75.9 & - & - & $\begin{array}{c}3.272 \\
(1.63-6.53) \\
p=0.001\end{array}$ & \multirow{2}{*}{$\begin{array}{l}\mathrm{D}-\mathrm{dimer} \geq 5.67 \mu \mathrm{g} / \mathrm{mL}, \mathrm{CRP} \geq 11.21 \\
\mathrm{mg} / \mathrm{L} \text { and type AAAD were } \\
\text { important risk factors and } \\
\text { independently associated with AAD } \\
\text { in-hospital death. }\end{array}$} \\
\hline & CRP & & $\geq 11.21 \mathrm{mg} / \mathrm{L}$ & $\begin{array}{c}100 \\
(74-89)\end{array}$ & 54.2 & - & - & $\begin{array}{c}2.322 \\
(1.13-4.75)\end{array}$ & \\
\hline
\end{tabular}




\begin{tabular}{|c|c|c|c|c|c|c|c|c|c|}
\hline & & & & & & & & $\mathrm{p}=0.021$ & \\
\hline \multirow[t]{5}{*}{$\begin{array}{l}\text { Pulmonary } \\
\text { embolism }\end{array}$} & BNP & $\begin{array}{c}261 \\
\text { Meta-analysis }^{121}\end{array}$ & $\begin{array}{l}75-100 \\
\mathrm{pg} / \mathrm{mL}\end{array}$ & $\begin{array}{c}85 \\
(64-95)\end{array}$ & $\begin{array}{c}56 \\
(50-62)\end{array}$ & $\begin{array}{c}98 \\
(94-99)\end{array}$ & $\begin{array}{c}14 \\
(9-21)\end{array}$ & $\begin{array}{c}6.5 \\
(2.0-21)\end{array}$ & \multirow{2}{*}{$\begin{array}{l}\text { The optimal cut-off value of BNP } \\
\text { and/or NT-proBNP for pulmonary } \\
\text { embolism has not been defined. }\end{array}$} \\
\hline & NT-proBNP & $\begin{array}{c}688 \\
\text { Prospective }^{122} \\
\end{array}$ & $600 \mathrm{pg} / \mathrm{mL}$ & $\begin{array}{c}86 \\
(69-95) \\
\end{array}$ & $\begin{array}{c}50 \\
(46-54) \\
\end{array}$ & $\begin{array}{c}99 \\
(97-100) \\
\end{array}$ & $\begin{array}{c}7 \\
(5-19) \\
\end{array}$ & $\begin{array}{c}6.3 \\
(2.2-18.3) \\
\end{array}$ & \\
\hline & \multirow[t]{2}{*}{ Troponin T } & $\begin{array}{c}682 \\
\text { Meta-analysis }^{89}\end{array}$ & $\begin{array}{l}\text { Different } \\
\text { Assays/cut- } \\
\text { off values }\end{array}$ & - & - & - & - & $\begin{array}{c}8.0 \\
(3.8-16.7)\end{array}$ & \multirow[t]{2}{*}{$\begin{array}{l}\text { Standardization of assays/cut-off } \\
\text { values in pulmonary embolism. }\end{array}$} \\
\hline & & $\begin{array}{c}526 \\
\text { Prospective }^{123}\end{array}$ & $14 \mathrm{pg} / \mathrm{mL}$ & $\begin{array}{c}87 \\
(71-95) \\
\end{array}$ & $\begin{array}{c}42 \\
(38-47) \\
\end{array}$ & $\begin{array}{c}98 \\
(95-99) \\
\end{array}$ & $\begin{array}{c}9 \\
(6-12) \\
\end{array}$ & $\begin{array}{c}5.0 \\
(1.7-14.4) \\
\end{array}$ & \\
\hline & H-FABP & $\begin{array}{c}126 \\
\text { Prospective }^{124}\end{array}$ & $6 \mathrm{ng} / \mathrm{mL}$ & $\begin{array}{c}89 \\
(52-99)\end{array}$ & $\begin{array}{c}82 \\
(74-89)\end{array}$ & $\begin{array}{c}99 \\
(94-99)\end{array}$ & $\begin{array}{c}28 \\
(13-47)\end{array}$ & $\begin{array}{c}36.6 \\
(4.3-304)\end{array}$ & Improve the use in clinical practice. \\
\hline
\end{tabular}

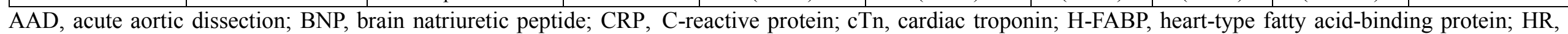

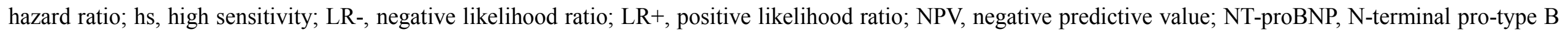
natriuretic peptide; OR, odds ratio; PPV, positive predictive value; -, not reported;

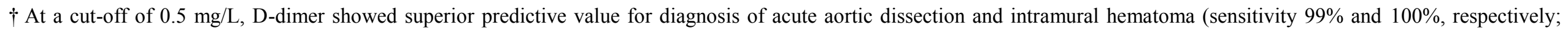
specificity $67 \%$ for both), than for penetrating aortic ulcer (sensitivity $64 \%$, specificity $67 \%$ ). 
Table 4. Biomarkers in critical chest diseases.

\begin{tabular}{|c|c|c|c|c|}
\hline Disease & Biomarker & Characteristics & Availability & References \\
\hline \multirow[t]{6}{*}{$\begin{array}{l}\text { Acute coronary } \\
\text { syndrome }\end{array}$} & Troponin & $\begin{array}{l}\text { - T- and I-isoforms are mostly applied to clinical use } \\
\text { - high sensitivity troponin assays are under clinical } \\
\text { testing }\end{array}$ & $\begin{array}{l}\text { Commercial } \\
\text { (US, EU) }\end{array}$ & {$[4,5]$} \\
\hline & Malondialdehyde LDL (MDA-LDL) & - marker of plaque formation & $\begin{array}{l}\text { Commercial } \\
\text { (US, EU, AP) }\end{array}$ & [9] \\
\hline & Pentraxin-3 (PTX3) & $\begin{array}{l}\text { - is produced by vascular endothelial cells and } \\
\text { macrophages } \\
\text { - reflects vascular inflammation }\end{array}$ & $\begin{array}{l}\text { Commercial } \\
\text { (US, EU, AP) }\end{array}$ & {$[11]$} \\
\hline & Oxidized phosphatidylcholine (OxPC) & - marker of plaque formation & Experimental & {$[8]$} \\
\hline & $\begin{array}{l}\text { Soluble lectin-like oxidized low-density } \\
\text { lipoprotein receptor-1 (sLOX-1) }\end{array}$ & $\begin{array}{l}\text { - is induced in response to proinflammatory stimuli, } \\
\text { angiotensin II and ox-LDL } \\
\text { - a receptor of ox-LDL }\end{array}$ & Experimental & {$[10]$} \\
\hline & Myeloperoxidase (MPO) & $\begin{array}{l}\text { - is released into extracellular fluid in response to } \\
\text { inflammatory processes }\end{array}$ & Experimental & [125] \\
\hline \multirow[t]{4}{*}{ Heart failure } & B-type natriuretic peptide (BNP) & $\begin{array}{l}\text { - is secreted by the ventricles in response to ventricular } \\
\text { overload }\end{array}$ & $\begin{array}{l}\text { Commercial } \\
\text { (US, EU, AP) }\end{array}$ & {$[62-67]$} \\
\hline & N-terminal pro-BNP (NT-proBNP) & - inactive form of BNP & $\begin{array}{l}\text { Commercial } \\
\text { (US, EU, AP) }\end{array}$ & {$[62-67]$} \\
\hline & Troponin & marker of myocyte death & $\begin{array}{l}\text { Commercial } \\
\text { (US, EU, AP) }\end{array}$ & {$[126]$} \\
\hline & Soluble ST2 & - marker of plaque formation & Commercial & {$[69]$} \\
\hline
\end{tabular}


Neutrophil gelatinase-associated

lipocalin (NGAL)

Cystatin $\mathrm{C}$

Galectin-3

\begin{tabular}{|c|c|}
\hline Aortic dissection & BB-isozyme of creatine (phospho-) \\
\hline & kinase \\
\hline & C-reactive protein \\
\hline & D-dimer \\
\hline
\end{tabular}

Smooth muscle myosin heavy chain

Calponin

Elastin

Matrix metalloprotease-9
- marker of renal function

Commercial

- marker of renal function

(US, EU, AP)

Commercial

- marker of cardiac and vascular fibrosis

Commercial

(US, EU, AP)

Commercial

- BB-isozyme is selective for neurological and smooth

(US, EU, AP)

muscle

- may help monitoring evolution of false lumen

Commercial

thrombosis

(US, EU, AP)

- a fibrin fragment seen in coagulation disorders - a rule- Commercial

in and rule-out marker - the only biomarker close to

(US, EU, AP)

gold-standard status, widely available for clinical use,

including rapid tests, due to its value in diagnosing acute

pulmonary embolism

- possible lack of elevations in intramural hematoma and thrombosed false lumen

- found in the aortic media layer

Experimental

- performance appropriate as a rule-in marker

- a troponin counterpart of smooth muscle

Experimental

- a structural protein in the vessel wall

- elevated in aortic dissection 


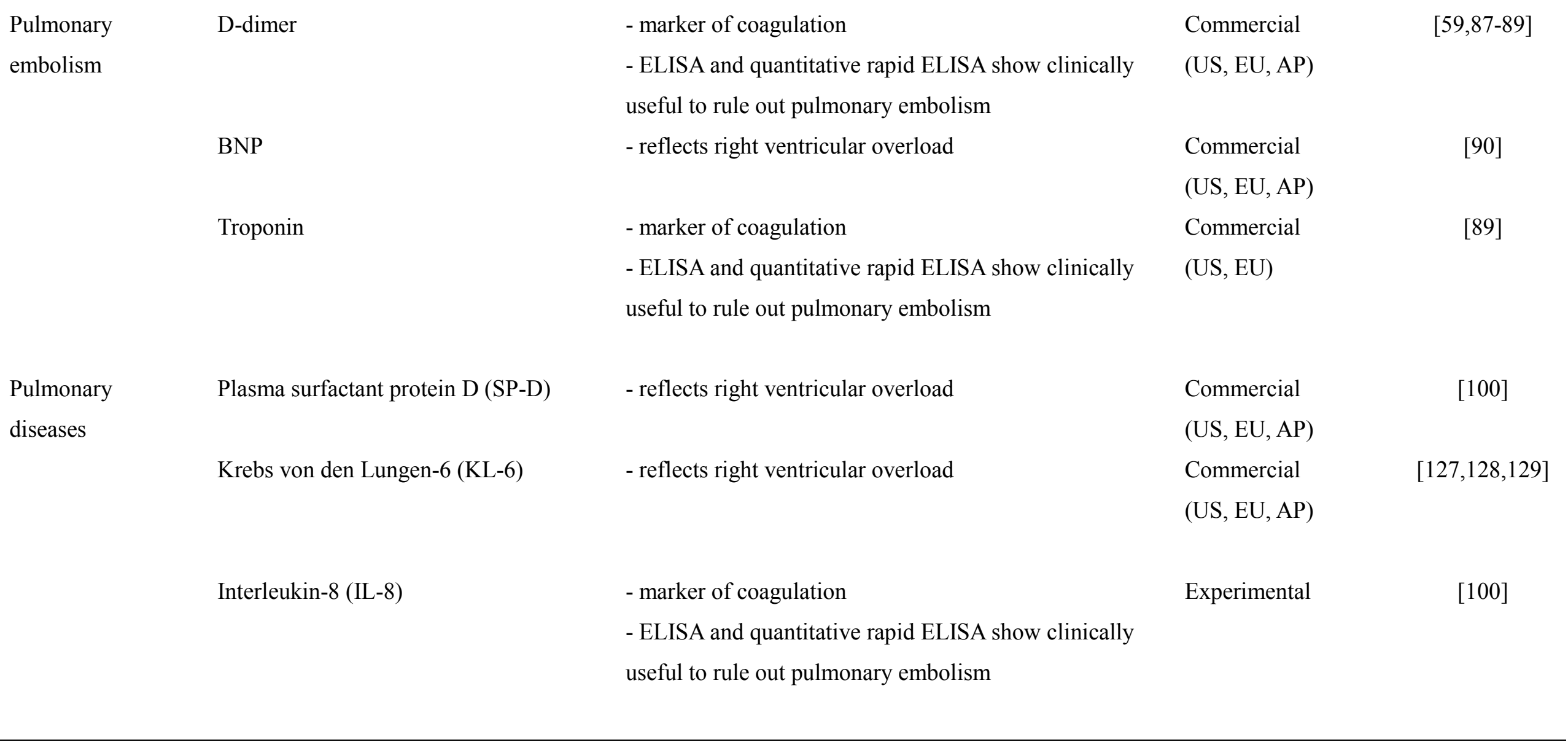

US, United States; EU, European Union; AP, Asia-Pacific. 


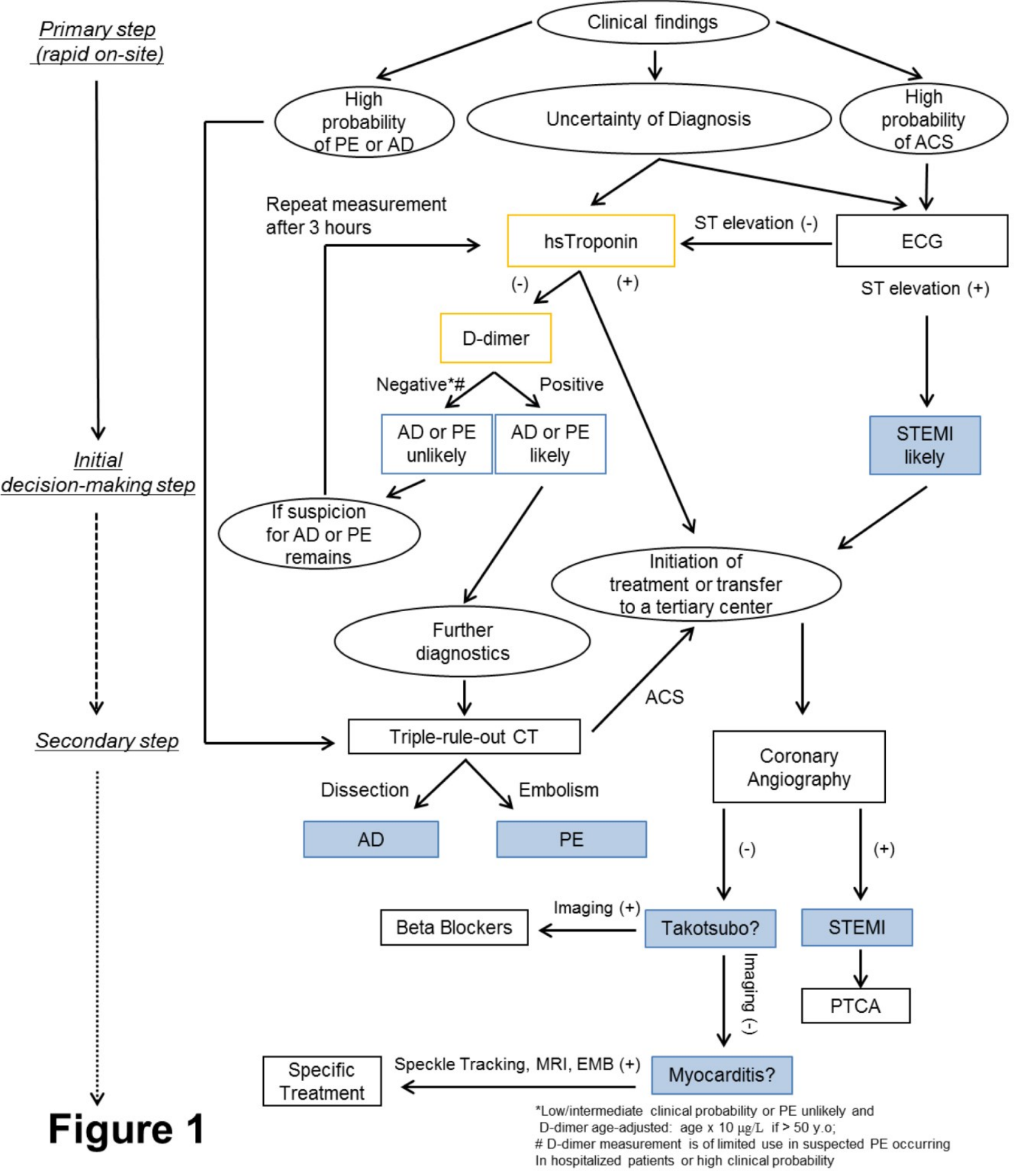




\section{Primary step (rapid on-site)}

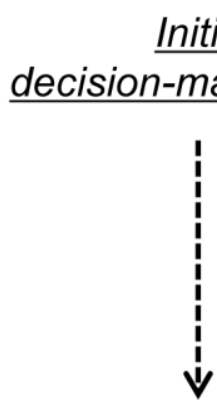

\section{Secondary step}

$$
\begin{gathered}
\vdots \\
\vdots \\
\vdots \\
\vdots \\
\vdots \\
\vdots \\
\vdots \\
\vdots \\
\vdots \\
\vdots \\
\vdots \\
\vdots \\
\vdots \\
\vdots \\
\vdots
\end{gathered}
$$

Figure 2

\section{Presentation with shortness of breath}

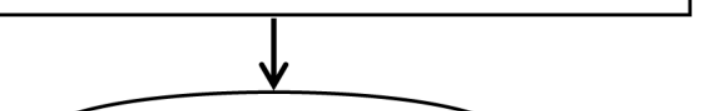

Clinical findings

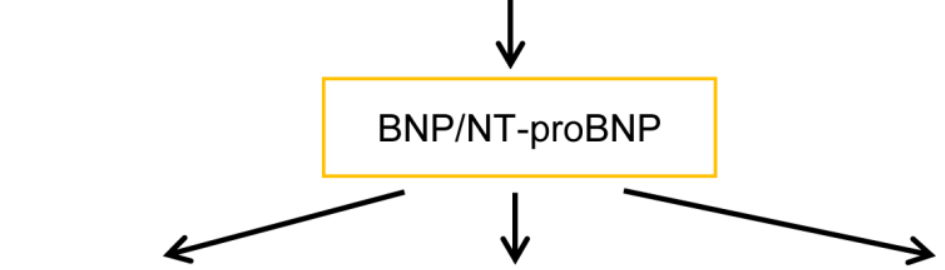

Low range

BNP $<100$

Middle range

$100 \leq B N P \leq 400$

NT-proBNP $<300$

$300 \leq N T-$ proBNP $\leq 1000$

High range

BNP $>400$

NT-proBNP $>1000$

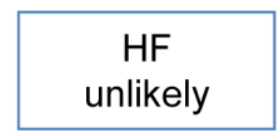

HF

suspected

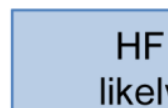

likely
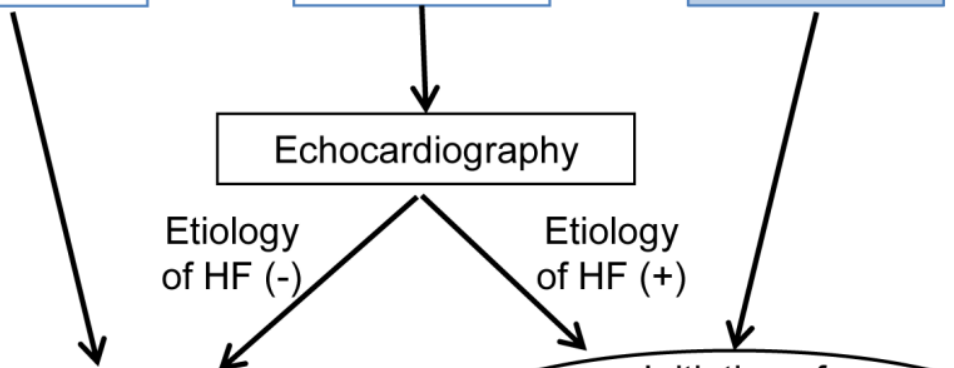

Initiation of

\section{D-dimer} treatment or transfer
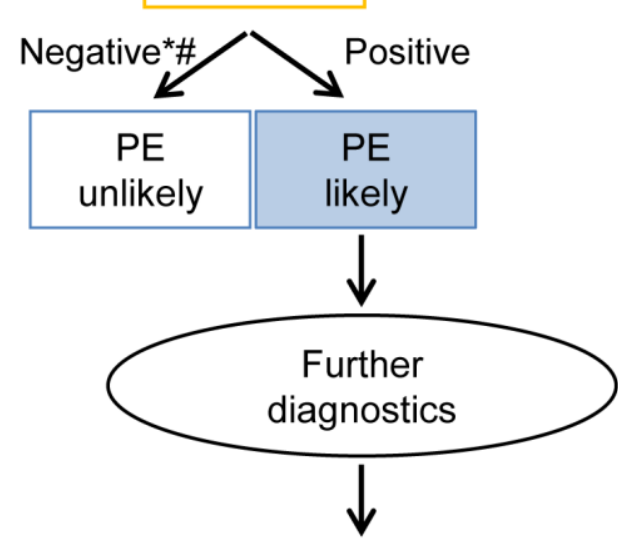

CT with enhancement

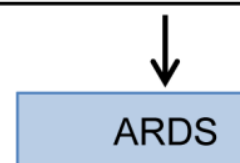

*Low/intermediate clinical probability or PE unlikely and D-dimer age-adjusted: age $\times 10 \mu \mathrm{g} / \mathrm{L}$ if $>50$ y.o;

\# D-dimer measurement is of limited use in suspected PE occurring In hospitalized patients or high clinical probability 
